\title{
Medicinal Plants and Natural Products Used in Cataract Management
}

\section{Devesh Tewari ${ }^{1 \dagger}$, Ovidiu Samoilă2t, Diana Gocan ${ }^{2}$, Andrei Mocan ${ }^{3 *}$, Cadmiel Moldovan ${ }^{3}$, Hari Prasad Devkota ${ }^{4}$, Atanas G. Atanasovv,6*, Gokhan Zengin ${ }^{7}$, Javier Echeverría ${ }^{8}$, Dan Vodnar ${ }^{9}$, Bianca Szabo ${ }^{10}$ and Gianina Crişan ${ }^{3}$}

\begin{abstract}
1 Department of Pharmacognosy, School of Pharmaceutical Sciences, Lovely Professional University, Phagwara, India, ${ }^{2}$ Department of Ophthalmology, Iuliu Haţieganu University of Medicine and Pharmacy, Cluj-Napoca, Romania, ${ }^{3}$ Department of Pharmaceutical Botany, Iuliu Haţieganu University of Medicine and Pharmacy, Cluj-Napoca, Romania, ${ }^{4}$ Graduate School of Pharmaceutical Sciences, Kumamoto University, Kumamoto, Japan, ${ }^{5}$ Institute of Genetics and Animal Breeding, Polish Academy of Sciences, Jastrzębiec, Poland, ${ }^{6}$ Department of Pharmacognosy, University of Vienna, Vienna, Austria, ${ }^{7}$ Department of Biology, Faculty of Science, Selcuk University, Konya, Turkey, ${ }^{8}$ Departamento de Ciencias del Ambiente, Facultad de Química y Biología, Universidad de Santiago de Chile, Santiago, Chile, ${ }^{9}$ Department of Food Science, University of Agricultural Sciences and Veterinary Medicine of Cluj-Napoca, Cluj-Napoca, Romania, ${ }^{10}$ Department of Anatomy, Iuliu Haţieganu University of Medicine and Pharmacy, Cluj-Napoca, Romania
\end{abstract}

\section{OPEN ACCESS}

Edited by:

Marco Leonti,

University of Cagliari, Italy

Reviewed by:

Dezső Csupor,

University of Szeged, Hungary

Guillermo Benítez,

University of Granada, Spain

*Correspondence:

Andrei Mocan

mocan.andrei@umfcluj.ro

Atanas G. Atanasov

a.atanasov.mailbox@gmail.com

${ }^{\dagger}$ These authors have contributed equally to this work and share first authorship

Specialty section:

This article was submitted to Ethnopharmacology,

a section of the journal Frontiers in Pharmacology

Received: 16 August 2018 Accepted: 12 April 2019

Published: 13 June 2019

Citation:

Tewari D, Samoilă O, Gocan D, Mocan A, Moldovan C, Devkota HP, Atanasov AG, Zengin G, Echeverría J,

Vodnar D, Szabo B and Crişan G (2019) Medicinal Plants and Natural

Products Used in Cataract Management.

Front. Pharmacol. 10:466. doi: 10.3389/fphar.2019.00466
Cataract is the leading reason of blindness worldwide and is defined by the presence of any lens opacities or loss of transparency. The most common symptoms of cataract are impaired vision, decreased contrast sensitivity, color disturbance, and glare. Oxidative stress is among the main mechanisms involved in the development of age-related cataract. Surgery through phacoemulsification and intraocular lens implantation is the most effective method for cataract treatment, however, there are chances of serious complications and irreversible loss of vision associated with the surgery. Natural compounds consisting of antioxidant or anti-inflammatory secondary metabolites can serve as potential leads for anticataract agents. In this review, we tried to document medicinal plants and plant-based natural products used for cataract treatment worldwide, which are gathered from available ethnopharmacological/ethnobotanical data. We have extensively explored a number of recognized databases like Scifinder, PubMed, Science Direct, Google Scholar, and Scopus by using keywords and phrases such as "cataract", "blindness", "traditional medicine", "ethnopharmacology", "ethnobotany", "herbs", "medicinal plants", or other relevant terms, and summarized the plants/phytoconstituents that are evaluated in different models of cataract and also tabulated 44 plants that are traditionally used in cataract in various folklore medical practices. Moreover, we also categorized the plants according to scientific studies carried out in different cataract models with their mechanisms of action.

Keywords: medicinal plants, natural products, cataract, antioxidant, aldose reductase, lens opacity, MAPK

\footnotetext{
Abbreviations: AGE, advanced glycation end products; AKR1B1, aldo-keto reductase family 1, member B1; AR, aldose reductase; ATP, adenosine triphosphate; BSA, bovine serum albumin; $\mathrm{Cx}$, connexin; EPHA2: FRSA, free radical scavenging activity; GPX, glutathione peroxidase; GSH, glutathione; IL, interleukin; iNOS, inducible nitric oxide synthase; LPO, lipid peroxides; MAPKs, mitogen-activated protein kinase; NADPH, nicotinamide adenine dinucleotide phosphate; PKC, protein kinase C; RLAR, rat lens aldose reductase; RNS, reactive nitrogen species; ROS, reactive oxygen species; SOD, superoxide dismutase; TGF- $\beta 2$, transforming growth factor $\beta_{2}$; TNF- $\alpha$, tumor necrosis factor- $\alpha$; UV, ultraviolet; VEGF, vascular endothelial growth factor; ZDF, zucker diabetic fatty.
} 


\section{CATARACT: AN OVERVIEW}

The crystalline lens lies behind the iris and represents the dynamic part of the eye's optical system, responsible for focusing the image onto the retina. Cataract is defined by the presence of any lens opacities or loss of transparency. The most common symptoms of cataract are impaired vision, decreased contrast sensitivity, color disturbance, and glare. Changes in the lens may also serve as markers for systemic health and aging in the over-all population (Song et al., 2014). According to the type of lens opacities, cataract is classified into three classical types: nuclear, posterior subcapsular, and cortical. These types can also be associated with each other and if untreated, they progress to total lens opacification. Some of the most common causes for cataract in adults are age, diabetes, steroid use, family history, or trauma. Congenital cataract has a significant prevalence, also.

Cataract is the foremost reason of blindness worldwide in spite of the technological advancements in eye surgery in the last two decades. In 2010, there were around 32 million blind people and 191 million were with poor vision. One in three blind people suffered from cataract (Khairallah et al., 2015). The World Health Organization (WHO) suggests that by 2020 the number of blind people will reach 90 million globally (Khairallah et al., 2015; Taylor, 2016). The strategy to fight this challenge is costly, aiming human resource, infrastructure development, and effective disease control. The latter is dependent on the characteristics of the specific disease. Prevalence of cataract increases with age, from 5\% for patients of age 52-62 to $64 \%$ for patients over 70 years, in Europe (Prokofyeva et al., 2013). Age is a non-modifiable risk factor involved in the pathogenesis of cataract, hence the progressive aging of the population is an alarming issue. Identifying modifiable risk factors for cataract is imperative and may help to establish the preventive measures.

The surgical treatment for cataract consists of cataractous lens extraction and intraocular lens implant. It is the only current treatment available in order for patients to recover their visual function. This implies a significant cost and there is a significant lack of access to surgery, especially in the developing world. Despite good postoperative outcomes, complications are possible following cataract surgery. Studies have suggested that pseudophakia patients have a higher risk of retinal detachment. Endophthalmitis has also been reported in $0.12 \%$ of the operated cases (Toh et al., 2007). After the surgery, the mobility of the lens is lost and correcting glasses are usually necessary. This will only increase the expense and the discomfort for the patient and society. Medical treatment would be a desired alternative.

The most primitive written reference to cataract surgery was discovered in Sanskrit manuscripts dating back from the 5th century BCE. It was attributed to Sushruta, a well-known ancient plastic surgeon who described a procedure known as couching, in which the cataractous lens was displaced with a sharp tool to fall it into the vitreous cavity, clearing the visual axis, though the vision was significantly blurred as there were no corrective lenses or glasses (Uhr, 2003; Sachdev, 2017). Even at the time of Mesopotamia (ca. 3,000-4,000 BCE) records reveal that mysticism along with different animal products, vegetables, and minerals were utilized for the treatment of devil and spirits causing eye diseases. Hundreds of remedies were also described during the Greek era (ca. 460-375 BCE) for disorders of the eyes. Moreover, eye diseases are also described anatomically by Sushruta (as mentioned above), Galen and various medicinal and surgical procedures were described for the treatment of eye diseases (Duke-Elder, 1962; Albert and Edwards, 1996; Goodman, 1996). In 1748, the introduction of modern cataract surgery was done by Jacques Daviel in Paris, in which the cataractous lens is removed from the eye. Later on in 1753, Samuel Sharp of London presented the intracapsular procedure, wherein the whole lens was removed by an incision by put on thumb pressure. In 1867 silk sutures for cataract surgery was originally described by Henry Willard Williams of Boston (Uhr, 2003).

\section{CATARACT - PATHOGENESIS}

Various mechanisms have been associated with age-related cataract pathogenesis. Lens opacities may appear due to changes in the microarchitecture, caused by mutations, biomechanical, or physical changes.

\section{Mutations}

Despite cataract being a multifactorial disease, sometimes mutations alone can cause lens opacities and this usually leads to congenital or pediatric cataract. Studies have presented more and more evidence that genetic factors are also part of age related cataract pathogenesis, raising the probability of molecular genetic relations between lens development and aging (Hejtmancik and Kantorow, 2004). Out of around 42 genes and loci that have been found to underlie congenital forms of cataract, a few of them have been linked with age associated cataract: EPHA2 (encodes a member of ephrin receptor of protein-tyrosinekinases), CRYAA, CRYGS (both encode lens proteins), FYCO1 (encodes a scaffolding protein which is active in microtubule transport of autophagic vesicle), or TDRD7 (encodes an RNAbinding protein). The mutation p.Gly18Val in CRYGS results in a protein with normal structure in physiological conditions. The alterations in its structure occur after thermal or chemical injury. A similar mutation is Phe71Leu in CRYAA. The discovery of mutations in genes coding for TDRD7, EPHA2, and FYCO1 has provided the initial evidence for the functional importance of posttranscriptional mRNA regulation, ephrin signaling, and the autophagy pathway, respectively, in human lens transparency (Shiels and Hejtmancik, 2015).

Gene mutations underlying secondary forms of cataract could also play part in age related cataract formation. A mutation in gene on $17 \mathrm{q}$ of galactokinase 1 (GALK1) which is responsible for encoding of the first enzyme in galactose metabolism, trigger autosomal recessive GALK1 1-deficiency with hypergalactosemia and cataract as a result of galactitol accumulation and osmotic stress. A coding variation in GALK1 (p.A198V) generates enzyme instability associated with amplified risk of age-related cataract in the Japanese population (Okano et al., 2001). 


\section{Oxidative Stress}

Oxidative stress is among the main mechanisms involved in the development of age-related cataract. Oxidative stress occurs when reactive compounds like the superoxide anion, hydroxyl radicals, and hydrogen peroxide are not neutralized by antioxidant enzymes and defense systems. Enzymes like catalase, SOD, and GPX are crucial for the homeostasis of the antioxidant system and ROS. When levels of ROS increase, this denatures the lens nucleic acids, proteins, and lipids, leading to mutations and cell apoptosis. Metabolic activities mostly take place in the lens epithelium. The lens epithelium uses the antioxidative enzymes in order to prevent damages caused by oxidative stress. Studies suggest that the highest concentration of SOD is in the lens epithelium (Rajkumar et al., 2013). These enzymes are also present in other parts of the lens and play a very important part in maintaining the lens clarity (Chang et al., 2013). SOD is responsible for converting superoxide anion into hydrogen peroxide, and then hydrogen peroxide is transformed into water by catalase or GPX. SOD enzyme activity is associated with cofactors like zinc, manganese, and copper. However, a decreased level of cofactors in cataractous lenses was not found. Experimental animal models show a decreased level of glutathione in the nucleus, therefore there is a higher susceptibility for oxidative damage and opacity formation (Giblin, 2000). Studies have shown that serum and aqueous humor levels of antioxidative enzymes are decreased in patients with cataract. However, there was no significant difference among different types of cataract and enzymes serum levels (Ohia et al., 2005; Wang et al., 2015).

\section{Crystallins Problems}

Crystallins, the major structural lens proteins have an imperative role in the lens transparency and acquire post-translational alterations during cataract formation, which lead to protein insolubility, aggregation and loss of lens transparency. Out of the three major crystallins, $\alpha-, \beta-$, and $\gamma-\alpha$ crystallins exhibit chaperone like activity, preventing them to aggregate. The chaperone activity is reduced in cataractous lenses. Prolonged hyperglycemic conditions increase the chances of crystallins deterioration (Reddy et al., 2014). Calcium activates calciumbinding proteins triggering changes in the shape and charge of the proteins. Elevated levels of calcium appear to induce proteolysis of crystallins by calpain, an intracellular cysteine protease. Activation of calpain, an intracellular cysteine protease, leads to proteolysis of the lens proteins. In order for calpains to activate, a high level of calcium is required (Obrosova et al., 2010). Studies demonstrate that the privation of an endogenous inhibitor of calpain, named calpastatin, could be linked to the initial changes that cause cataract (Nakajima et al., 2014). Some antioxidants have been reported to regulate calcium influx in selenite induced cataracts, for instance the flavonoid fraction of Brassica oleracea (Vibin et al., 2010).

\section{Protein Structures}

Alterations in the protein structure are also determined by UV exposure. Studies have shown that UVB generates more damage than UVA and that damages are prevented by the lens filters. After UV radiations, proteins suffer chemical reactions resulting in aggregations, decreasing the transparency of the lens (Cetinel et al., 2017). The crystalline lens is particularly exposed to phototoxic damage, because it absorbs most of UV radiation, together with cornea. The main association is with cortical cataract, most of the absorption occurring at the posterior surface of the lens. UV radiation can generate free radicals including oxygen-derived species, that cause lipid peroxydation of cellular membranes or can damage DNA directly (Youn et al., 2011). In vivo, induced cataract has no absolute threshold for UV exposure. UV induced cataract for in vivo exposure at UV$300 \mathrm{~nm}$ has a continuous dose-response function (Söderberg et al., 2016). UV radiation data from Eurosun library implied that rates of cataract were higher in regions with higher ambient UV-B radiation levels (Delcourt et al., 2014).

\section{MEDICINAL PLANTS AND NATURAL PRODUCTS USED AGAINST CATARACT}

Opacity of the lens is triggered by free radicals in most of the cases (Varma et al., 1984; Thiagarajan and Manikandan, 2013). Severe oxidative stress also leads to the protein modifications by free radicals, and several natural products from plants are helpful in the prevention of proteins insolubilization, which may delay the opacity of lenses (Bhadada et al., 2016b). Natural compounds constituting of antioxidant or anti-inflammatory secondary metabolites could be viewed as potentially optimal anticataract agents as antioxidant effect is among the major mechanisms for prevention of cataract in most of the cases, however, not all the plants possessing antioxidant potential could have anticataract properties. The role of plant polyphenols in anti-cataractogenic activities is also studied in the comprehensive manner either in vitro or in vivo (Rooban et al., 2009, 2011; Kim et al., 2011c; Wang et al., 2011; Sasikala et al., 2013; Sunkireddy et al., 2013; Ferlemi et al., 2016).

Although there is substantial basic and applied research in the field of cataract management by natural products, mostly ethno-pharmacological/ethnobotanical research, there are not many review papers available about the activity analysis of natural products against different cataract models. One paper focused on antioxidant containing plants against cataract was found with 41 plants investigating anti-cataract activity (Thiagarajan and Manikandan, 2013). Although there are few ethnopharmacological surveys and their reviews available (Maregesi et al., 2017), there is no detailed review available on the activities of different plants extracts and natural products in cataract models.

\section{METHODOLOGY AND HYPOTHESIS}

In this work, we attempted to gather and document the widely scattered information from various preclinical investigations and ethnopharmacological reports. We searched several web databases namely, Scifinder, ScienceDirect, Pubmed, Scopus, 
and Google Scholar. Boolean information retrieval method (Pohl et al., 2010) was applied using plant name with "AND" operator as also done in some other systemic reviews (Tewari et al., 2017, 2018) followed by "cataract" and using other different keywords such as "cataract", "traditional medicine", "ethnobotany", "sodium selenite", and "ethnopharmacology".

The main research question we try to address in this paper is: "are medicinal plants/natural products used in various folk and traditional medicine of importance in the management of cataract?" and "what are the major preclinical in vitro/in vivo models that are used globally for the evaluation of cataract?". We hypothesize that plants used in ethnomedicine are not only of potential importance but also preclinical studies conducted on various models of cataract could result in the development of potential drug candidates in future. This could be very rewarding for the scientists and scholars working in this area and also very beneficial for the patients to take forward the preclinically effective plants for clinical studies.

\section{RESULTS}

Oxidative stress is involved in activation of MAPKs. Compounds resulted from the activation of MAPKs have been studied and were associated with cell apoptosis. The p38 MPAK was studied in vitro and it was shown that it is activated by hydrogen peroxide,

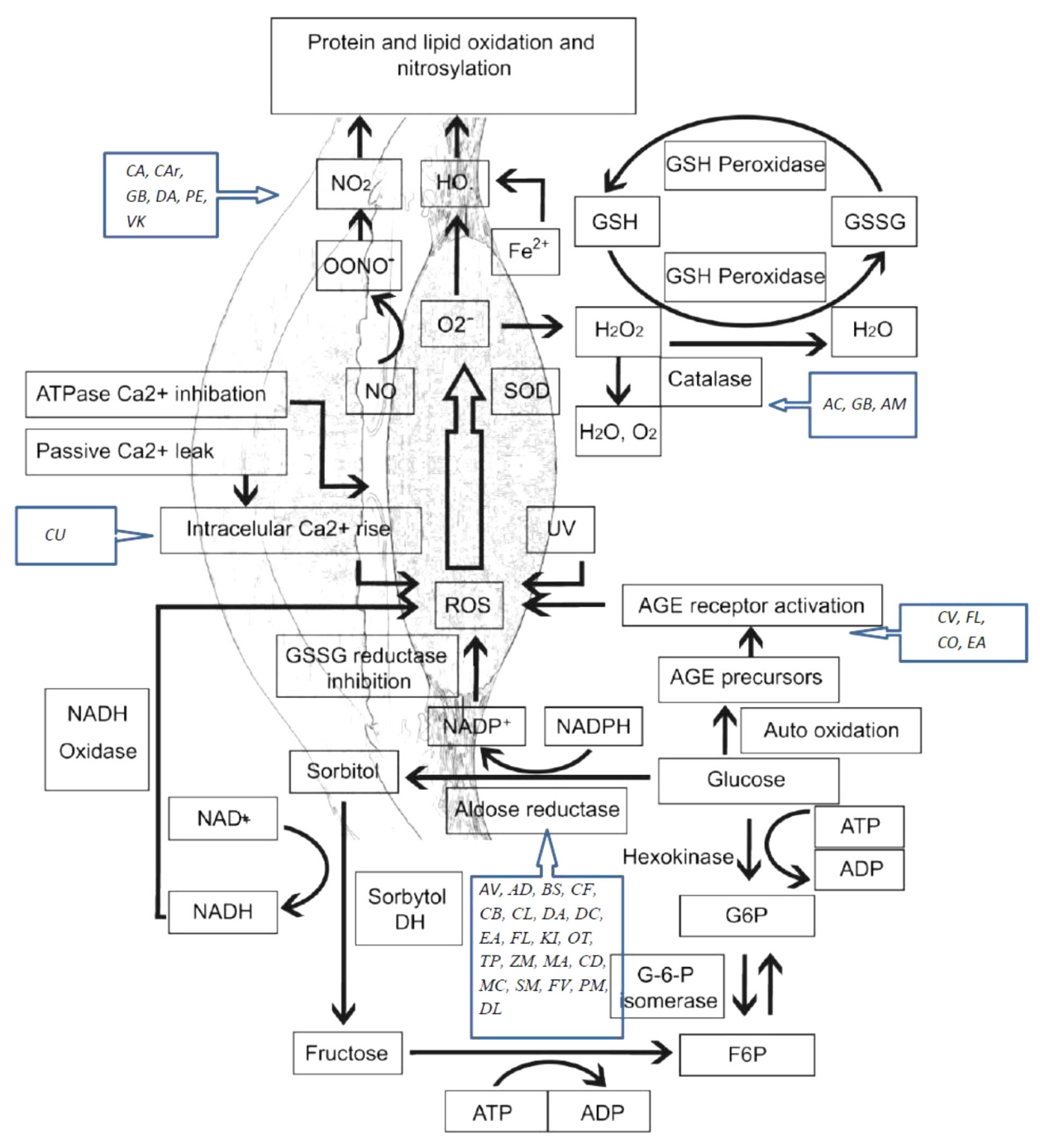

FIGURE 1 | Oxidative stress mechanisms involved in cataract etiology and action mechanisms of several medicinal plants with conducted pharmacological studies for the treatment of cataract. AGE, advanced glycation end-products; ROS, reactive oxygen species; SOD, superoxide dismutase; GSH, glutathione; GSSG, glutathione disulfide; NO, nitric oxide. AC, Allium cepa; CA, Coffea arabica; CU, Curcumin; GB, Ginkgo biloba; AV, Adhatoda vasica; AM, Aegle marmelos; AD, Angelica dahurica; BS, Biophytum sensitivum; CB, Caesalpinia bonduc; CF, Cassia fistula; CV, Cinnamomum verum; CL, Curcuma longa; DA, Dendrobium aurantiacum var. denneanumis; DC, Dendrobium chrysotoxum; EA, Erigeron annuus; FL, Flavonoids; KI, KIOM-79; OT, Ocimum tenuiflorum; VK, Vitamin K; TP, Tephrosia purpurea; ZM, Zea mays; MA, Matteuorienate A; CD, Caesalpinia digyna; CO, Cornus officinalis; MC, Morinda citrifolia; SM, Salvia miltiorrhiza; FV, Foeniculum vulgare; PM, Pueraria montana; DL, Danshenol; C Ar, Citrus aurantium; PE, Phyllanthus emblica. 
TABLE 1 | Medicinal plants/natural products used against cataract on Selenite/sodium selenite induced cataract models, and suggested/possible mechanisms of action.

\begin{tabular}{lll}
\hline Plant (with part & $\begin{array}{l}\text { Doses, concentrations and } \\
\text { characteristics of extracts }\end{array}$ & Suggested/possible mechanism of action \\
used)/natural product & References
\end{tabular}

Alangium salviifolium (L.f.) Wangerin (Syn. Alangium lamarckii Thwaites) (Leaves)

Allium cepa L. (Tuber/bulb)

Alcoholic extract at an increasing concentration between 0 and $300 \mu \mathrm{g} / \mathrm{mL}$ $\left(\mathrm{IC}_{50} 106 \pm 5.11 \mu \mathrm{g} / \mathrm{mL}\right)$

$50 \%$ diluted juice

Allium sativum L. (Tuber/bulb)

Aralia elata (Miq.) Seem. (Cortex)

Brassica oleracea L. var. italica Plenck (Edible part)

Caesalpinia digyna Rottler (Roots)

Caffeic acid phenethyl ester

Camellia sinensis (L.)

Kuntze (Leaves)

Cassia fistula L. (Fruit pulp)

Cochlospermum religiosum

(L.) Alston (Leaves)

Coffea arabica L.

Crataegus pinnatifida Bunge (Leaves)

Crocus sativus L. (Stigmas)

Curcuma longa L.

(Rhizomes)

Cyanthillium cinereum (L.) H. Rob. (Syn. Vernonia cinerea Less.) (Leaves)

Dregea volubilis (L.f.) Benth. ex Hook.f. (Leaves)

Ellagic acid

Emilia sonchifolia (L.) DC. ex DC. (Whole plant)

Enicostemma hyssopifolium (Willd.) Verd. (Aerial parts)
Aqueous extract, $1 \mathrm{~mL} / \mathrm{kg}$ body weight

Aqueous extract at 1 and $10 \mathrm{mg} / \mathrm{mL}$ ( $\left.\mathrm{IC}_{50} 11.3 \mu \mathrm{g} / \mathrm{mL}\right)$

Flavonoid fraction

Alcoholic extract at an increasing concentration between 0 and $200 \mu \mathrm{g} / \mathrm{mL}$ $\left(\mathrm{IC}_{50} 46.29 \pm 11.17 \mu \mathrm{g} / \mathrm{mL}\right)$

Caffeic acid phenethyl ester, subcutaneous

Extract ( $1 \mathrm{~L}$ of the solution contains $100 \mathrm{~g}$ and $535 \mathrm{~mL}$ of strong alcohol), intraperitoneally

Sequential water, ethanol and chloroform extracts

Isolated isorhamnetin-3-glucoside, $50 \mu \mathrm{g} / \mathrm{mL}$

$1 \mathrm{~mL}$ of Instant black coffee

Total flavonoids fraction

Hydroalcoholic extract, intraperitoneal injections of saffron extract $(60 \mathrm{mg} / \mathrm{kg}$ body weight)

Curcumin (200 $\mu \mathrm{M})$

Isolated lupeol from flavonoid fraction that showed an $\mathrm{IC}_{50} 30 \mu \mathrm{g} / \mathrm{mL}$ against DPPH

Isolated drevogenin D, $50 \mu \mathrm{g} / \mathrm{mL}$

Ellagic acid $200 \mathrm{mg} / \mathrm{kg}$ body weight, i.p.

Flavonoid fraction $1.0 \mathrm{mg} / \mathrm{kg}$ body weight, i.p.

C-glycosidic flavonoid including extract

(IC50 1.62; bitter fraction 2.40,

Swertiamarin 7.59 and Swertisin

$0.71 \mu \mathrm{g} / \mathrm{mL}$ ) of green tea, $400 \mathrm{~mL}$ of purified water
Exhibit significant inhibitory effects on aldose reductase $(A R)$ in the rat lens in vitro.

Prevention of selenite-induced cataract formation by increase in superoxide dismutase (SOD) and total antioxidant level and activities of glutathione peroxidase (GPX) in lens through instillation of juice in rat eyes.

Free radical scavenging activity (FRSA), antioxidant properties and associated with increased TA level, SOD and GPX activities in the lens.

Inhibit AR and antioxidant activity.

Maintains antioxidant status, ionic balance via $\mathrm{Ca}^{2+}$ ATPase pump, inhibits calpain activation, lipid peroxidation, and protein insolubilization.

AR inhibition.

Kumar et al., 2011

Javadzadeh et al., 2009b

Javadzadeh et al., 2009a

Chung et al., 2005

Vibin et al., 2010

Kumar et al., 2011

Suppressed cataract formation in rats by antioxidant property.

Antioxidant activity.

Doganay et al., 2002

Gupta et al., 2002

AR inhibition.

Gacche and Dhole, 2011a

Retardation of selenite cataract in vitro via preventing oxidative stress, calcium accumulation and preclusion of lipid peroxidation.

Decreased level of total nitric oxide, tumor necrosis factor- $\alpha$ (TNF- $\alpha)$, Ca-ATPase, superoxide dismutase, interleukin (IL)-1 $\beta$, preserved enzyme antioxidants and lens proteins.

Inhibition of AR, FRSA.

Gayathri Devi et al., 2010

El Okda et al., 2016

Wang et al., 2011

Reinforcement of antioxidant condition, inhibits lipid peroxidation intensity, and inhibition of aqueous-soluble fraction of lens proteolysis.

Oxidative stress inhibition and attenuation to cataract formation, ameliorated calcium-induced proteolysis.

Protection against formation of nuclear opacity in selenite-treated Sprague Dawley rat pups.

Antioxidant activity (affecting glutathione peroxidase, superoxide dismutase, catalase, and glutathione reductase), raises reduced glutathione and protein sulfhydryl levels, and decreases the lipid peroxidation levels.

Inhibition of lipid peroxidation and maintains antioxidant defense system.

Antioxidant activity.

AR inhibition.
Sakthivel et al., 2008

Lija et al., 2006

Makri et al., 2013

Manikandan et al., 2009; Liao et al., 2016

Asha et al., 2016

Biju et al., 2007

Patel and Mishra, 2009

(Continued) 
TABLE 1 | Continued

\begin{tabular}{ll}
$\begin{array}{l}\text { Plant (with part } \\
\text { used)/natural product }\end{array}$ & $\begin{array}{l}\text { Doses, concentrations and } \\
\text { characteristics of extracts }\end{array}$ \\
\hline $\begin{array}{l}\text { Eucalyptus deglupta Blume } \\
\text { (Not given) }\end{array}$ & Ethanolic extract \\
Ginkgo biloba L. (Egb761) & $\begin{array}{l}\text { Extract } 761(0.35 \% 100 \mathrm{mg} / \mathrm{kg} \text { body } \\
\text { weight) }\end{array}$
\end{tabular}

Jacobaea maritima (L.) Pelser \& Meijden [Syn. Cineraria maritima (L.) L.] (Aerial parts)

Vitex negundo L. (Leaves)

Moringa oleifera Lam. (Leaves)

Origanum vulgare L. (Upper crust of beans)

Phyllanthus emblica L. (Syn. Emblica officinalis Gaertn.) (Fruits)

Pleurotus ostreatus (Jacq. ex Fr.) P.Kumm.

(Mushroom)

Rutin

Senna tora (L.) Roxb. (Syn. Cassia tora L.) (Leaves)

Spathodea campanulata P.Beauv. (Flowers)

Syzygium malaccense (L.) Merr. \& L.M.Perry (Not mentioned)

Tagetes erecta L. (Flowers)

Tephrosia purpurea (L.) Pers. (Whole plant)

Trigonella foenum-graecum L. (Seeds)

Triphala [An Ayurvedic formulation consisting of Emblica officinalis Gaertn., Terminalia chebula Retz., and Terminalia bellirica (Gaertn.) Roxb.]

Vaccinium corymbosum L. (Leaves)

Vitex negundo L.

Vitex negundo L. (Leaves)

\section{Ethanolic extract $(300 \mu \mathrm{g} / \mathrm{mL})$}

Flavonoids

Flavonoid fraction $2.5 \mu \mathrm{g} / \mathrm{g}$ body weight

Hydroethanolic extract (70\%), 2 g/kg

Aqueous extract, 26.19 mg/kg

Rutin

Ethyl acetate fraction having anthraquinones and flavonoids, $5 \mu \mathrm{g} / \mathrm{g}$ body weight

Exudate, 0.1 and $0.2 \mathrm{mg} / \mathrm{mL}$

Ethanolic extract

Lutein and its ester at doses of 4,40 , and $400 \mathrm{mg} / \mathrm{kg}$ body weight

Flavonoid rich fraction $(40 \mathrm{mg} / \mathrm{kg})$ or alcohol extract (300 mg/kg)

Lyophilized aqueous extract, $(25,50$, and $100 \mu \mathrm{g} / \mathrm{mL}$ )

Aqueous extract at 25, 50, and $75 \mathrm{mg} / \mathrm{kg}$ body weight i.p.

Decoctions (centrifuged, filtered, lyophilized), and dry extract, dissolved in sterilized normal saline, $100 \mathrm{mg} / \mathrm{kg}$

Flavonoids
Ethanolic extract $250 \mu \mathrm{g} / \mathrm{mL}$
Luteolin
Suggested/possible mechanism of action

References

AR inhibition.

Guzman and Guerrero, 2005

Prevents depletion of antioxidant enzymes, reduces oxidative stress, inhibition of lipid peroxidation and suppression of the TGF- $\beta 2 / S m a d$ pathway activation.

Increase in the activity of antioxidant enzymes and increase in the level of reduced glutathione in lens, reduces free radical generation.

Maintenance of antioxidant status, by inhibition of ROS generation/lipid peroxidation in lens.

Improvement of total antioxidant capability in lens, prevention of protein oxidation and lipid peroxidation.

Averts selenite-induced cataract through its antioxidant property.

Inhibition of sodium selenite induced cataract in rats though antioxidant property.

Reduction of lipid peroxidation and increase in antioxidant enzymes.

Alteration in protein profile and insolubilization of soluble protein.

Prevention of cytoskeletal protein denaturation in the lens, improvement of antioxidant capacity, and reduction in free radical generation.

Counteracts cataract by antioxidant activity.

AR inhibition.

Antioxidant activity.

Maintenance of the antioxidant status and prevention of protein oxidation and lipid peroxidation in lens.

Antioxidant.

Restoration of GSH and reduced

malondialdehyde levels. Substantial restoration in antioxidant enzymes activities like glutathione peroxidase, superoxide dismutase, catalase, and glutathione-s-transferase.

Direct and indirect inhibition of lens calpains, anti-oxidant and chelating properties.

Enhancement of antioxidant enzymes, maintains ionic balance and reduces the lens oxidative stress, prevention of changes in lens protein, loss of chaperone property, changes in lens structure, protective effect against oxidative damage.

Maintenance of antioxidant status via reducing ROS generation/lipid peroxidation in lens.
Lu et al., 2014; Cao et al., 2015

Anitha et al., 2011, 2013

Rooban et al., 2012

Sasikala et al., 2010

Dailami et al., 2010

Nair et al., 2010

Isai et al., 2009

Sasikala et al., 2013

Sreelakshmi and Abraham, 2016

Gbemisola et al., 2014

Guzman and Guerrero, 2005

Harikumar et al., 2008

Bhadada et al., 2016a

Gupta et al., 2010b

Gupta et al., 2010a

Ferlemi et al., 2016

Rooban et al., 2009, 2010, 2011

Rooban et al., 2012 
TABLE 1 | Continued

\begin{tabular}{|c|c|c|c|}
\hline $\begin{array}{l}\text { Plant (with part } \\
\text { used)/natural product }\end{array}$ & $\begin{array}{l}\text { Doses, concentrations and } \\
\text { characteristics of extracts }\end{array}$ & Suggested/possible mechanism of action & References \\
\hline Vitis vinifera L. (Seed extract) & Proanthocyanidin/procyanidin-rich extract & $\begin{array}{l}\text { Oxidative stress inhibition, suppression of lipid } \\
\text { peroxidation, and free radicals and activation of } \\
\text { inducible nitric oxide synthase (iNOS), and calpain II } \\
\text { in lenses. Improvement of the antioxidant defense } \\
\text { mechanisms of the lens. }\end{array}$ & $\begin{array}{l}\text { Yamakoshi et al., 2002; } \\
\text { Durukan et al., 2006; } \\
\text { Zhang and Hu, 2012; } \\
\text { Mani Satyam et al., 2014 }\end{array}$ \\
\hline $\begin{array}{l}\text { Withania somnifera (L.) Dunal } \\
\text { (Procured extract) }\end{array}$ & Aqueous extract, $25-300 \mu \mathrm{g} / \mathrm{mL}$ & Inhibits lens AR activity. & Halder et al., 2003 \\
\hline
\end{tabular}

TABLE 2 | Medicinal plants/natural products used against cataract on preventing photo-oxidative damage.

\begin{tabular}{|c|c|c|c|}
\hline $\begin{array}{l}\text { Plant (with part used)/ } \\
\text { natural product }\end{array}$ & $\begin{array}{l}\text { Doses, concentrations and } \\
\text { characteristics of extracts }\end{array}$ & Suggested/possible mechanism of action & References \\
\hline Astaxanthin & Astaxanthin (0-1 mM) & $\begin{array}{l}\text { Prevention of cataract through protection of } \\
\text { lens from oxidative insults and degradation by } \\
\text { calcium-induced calpain. }\end{array}$ & Wu et al., 2006 \\
\hline Citrus $\times$ aurantium L. (Peel) & $\begin{array}{l}\text { Methanol-water extract, } 100 \text { and } \\
200 \mathrm{mg} / \mathrm{kg} \text { body weight }\end{array}$ & $\begin{array}{l}\text { Delay in onset and maturation of naphthalene } \\
\text { induced cataract vis prevention of the } \\
\text { photo-oxidative damage produced by } \\
\text { naphthalene. }\end{array}$ & Umamaheswari et al., 2011 \\
\hline Ginkgo biloba L. (Leaves) & $\begin{array}{l}\text { Standardized EGb761 extract ( } 24 \% \text { flavonol } \\
\text { glycoside and } 6 \% \text { terpene lactones) }\end{array}$ & $\begin{array}{l}\text { Protection from radiation induced cataracts in } \\
\text { rat lens via antioxidant property. }\end{array}$ & Ertekin et al., 2004 \\
\hline Lutein and Zeaxanthin & Lutein and Zeaxanthin & $\begin{array}{l}\text { Protection of eye from oxidative stress and } \\
\text { high-energy photons of blue light. }\end{array}$ & Moeller et al., 2000 \\
\hline
\end{tabular}

induce cell apoptosis in lens epithelial cells and the antioxidant agents could reduce its effects. Inhibitors of p38 MAPK reduced ROS levels and apoptosis (Bai et al., 2015).

Lipids peroxidation is also a reason of age related cataract. This process has a negative impact on lipid-lipid and lipid-protein interactions. Research has shown high levels of hydroperoxides, oxy derivatives, and diene conjugates of phospholipid fatty acids in the aqueous humor of cataract patients. Also, studies have reported high levels of oxidation products of linoleic acid in patients with early cataract (Bai et al., 2015). A schematic representation of oxidative stress mechanisms involved in cataract etiology and action mechanisms of several medicinal plants with conducted pharmacological studies for the treatment of cataract are presented in Figure 1.

Polyol pathway is associated with diabetic cataract. Enzymes implicated in the polyol pathway, sorbitol dehydrogenase and AR are responsible for the conversion of glucose to fructose. Sorbitol, an intermediate compound, was found to produce cell lesions by modifying the membrane permeability. Therefore, accumulation of sorbitol leads to osmotic stress, collapse, and liquefaction of lens fibers resulting in loss of lens transparency (Pollreisz and Schmidt-Erfurth, 2010; Hashim and Zarina, 2012). AR converts glucose to sorbitol, dependent to NADPH. As a consequence, the level of NADPH decreases, also having a negative impact on the glutathione activity and the antioxidant system. In vivo and in vitro studies have shown that by inhibiting the activity of $\mathrm{AR}$, the progression to cataract in patients with diabetes is reduced (Kim et al., 2011a; Ramana, 2011). The glycosylation pathway has also been linked to diabetic cataract. Excessive glucose level induces the glycation of proteins, generating superoxide radicals and AGEs in the process. Recent studies suggest that there is interdependence between the oxidative stress and polyol pathway, through AR and iNOS, responsible for the nitric oxide production during oxidation (Snow et al., 2015; Li et al., 2017) (Figure 1).

Here, we present details of plants evaluated against cataract with discussion of their possible mechanism of action (Figure 1 and Tables 1-4). Some important chemical structures of the natural products that are used against cataract or found in plants used in the management of cataract are also presented at Figure 2 (not all chemical structures are presented). We categorized the plants based upon the models evaluated. Table 1 describes the natural products used against cataract evaluated on selenite/sodium selenite induced cataracts, in Table 2 natural products used against cataract on preventive photooxidative damage is described, Table 3 deals with the natural products used against cataract on sugar-induced lens opacity/Streptozotocin induced diabetic cataract/galactose or glucose induced/ZDF models, in Table 4 AGEs-BSA crosslinking inhibition assay and lens AR activity models are described, and Table 5 describes the natural products used against cataract on hydrogen peroxide and naphthalene induced cataract and other miscellaneous models.

Like in case of any other disease conditions, medicinal plants are being used in management of various eye ailments from ancient times. Medicinal plants are used in case of cataract, eye infections, conjunctivitis, eye dryness, and other eye disorders in many countries including India (Sandhu et al., 2011; Das et al., 2013; Rothe and Maheshwari, 2016), Bangladesh (Yusuf et al., 2006; Das et al., 2007, 2013), Nepal (Manandhar, 2002; Acharya and Pokhrel, 2006; Gewali, 2011; 
TABLE 3 | Medicinal plants/natural products used against cataract on sugar-induced lens opacity/streptozotocin induced diabetic cataract/galactose, glucose and xylose induced/Zucker diabetic fatty (ZDF) aldose reductase rat models and possible mechanisms of action.

\begin{tabular}{|c|c|c|c|}
\hline $\begin{array}{l}\text { Plant (with part used)/natural } \\
\text { product }\end{array}$ & $\begin{array}{l}\text { Doses, concentrations and } \\
\text { characteristics of extracts }\end{array}$ & $\begin{array}{l}\text { Suggested/possible } \\
\text { mechanism of action }\end{array}$ & References \\
\hline Aegle marmelos (L.) Corrêa (Leaves) & $\begin{array}{l}\text { Chloroform extract } 150 \mathrm{mg} \text { and } \\
300 \mathrm{mg} / \mathrm{kg} \text { body weight, p.o. }\end{array}$ & $\begin{array}{l}\text { Increases glutathione, catalase and } \\
\text { superoxide dismutase, inhibits lens AR and } \\
\text { decreases osmotic stress. }\end{array}$ & $\begin{array}{l}\text { Panaskar et al., 2013; } \\
\text { Sankeshi et al., } 2013\end{array}$ \\
\hline Allium sativum L. (Bulb) & $\begin{array}{l}\text { Methanolic extract, } 0.25 \text { and } 0.5 \mathrm{~g} / \mathrm{kg} \\
\text { body weight, by forcible gut feeding }\end{array}$ & Antioxidant activity. & Raju et al., 2008 \\
\hline $\begin{array}{l}\text { Angelica dahurica (Hoffm.) Benth. \& } \\
\text { Hook.f. ex Franch \& Sav. (Roots) }\end{array}$ & $\begin{array}{l}\text { Ether extract }(100 \mu \mathrm{g} / \mathrm{mL}) \\
\text { (Byakangelicin) }\end{array}$ & $\begin{array}{l}\text { Suppression of galactose induced cataract } \\
\text { formation in diabetic rats via AR inhibiting } \\
\text { property. }\end{array}$ & Shin et al., 1994, 1998 \\
\hline Buddleja officinalis Maxim. (Flowers) & Apigenin & Inhibiting rat lens AR activity. & Matsuda et al., 1995 \\
\hline $\begin{array}{l}\text { Azadirachta indica A. Juss. (Not } \\
\text { mentioned) }\end{array}$ & Aqueous extract, 25-300 $\mu \mathrm{g} / \mathrm{mL}$ & Inhibits lens AR activity. & Halder et al., 2003 \\
\hline Biophytum sensitivum (L.) DC. (Leaves) & $\begin{array}{l}\text { Sequential water, ethanol and } \\
\text { chloroform extracts }\end{array}$ & AR inhibition and antioxidant action. & Gacche and Dhole, 2011a \\
\hline Brassica juncea (L.) Czern. (Leaves) & Aqueous extract, 250 and 500 mg/kg & $\begin{array}{l}\text { Effective activity against hyperglycemia } \\
\text { induced oxidative and osmotic stress. }\end{array}$ & Valavala et al., 2011 \\
\hline $\begin{array}{l}\text { Brickellia arguta B. L. Rob (Not } \\
\text { mentioned) }\end{array}$ & Ethanolic extract & AR inhibition. & Guzman and Guerrero, 2005 \\
\hline Caesalpinia bonduc (L.) Roxb. (Seeds) & $\begin{array}{l}\text { Sequential water, ethanol and } \\
\text { chloroform extracts }\end{array}$ & AR inhibition and antioxidant. & Gacche and Dhole, 2011a \\
\hline Cassia fistula (L.) (Fruit pulp) & $\begin{array}{l}\text { Sequential water, ethanol and } \\
\text { chloroform extracts }\end{array}$ & AR inhibition and antioxidant. & Gacche and Dhole, 2011a \\
\hline $\begin{array}{l}\text { Catharanthus roseus (L.) G.Don } \\
\text { (Leaves) }\end{array}$ & $\begin{array}{l}\text { Sequential water, ethanol and } \\
\text { chloroform extracts }\end{array}$ & Inhibiting AR activity and antioxidant action. & Gacche and Dhole, 2011b \\
\hline Chlorogenic acid & Chlorogenic acid (0.7-2.8 mM) & Inhibiting AR activity in galactose fed rats. & Kim et al., 2011a \\
\hline $\begin{array}{l}\text { Chromolaena odorata (L.) R.M.King \& } \\
\text { H.Rob. (Leaves) }\end{array}$ & Ethanol extract (200 and 400 mg/kg) & Decrease of oxidative stress. & Onkaramurthy et al., 2013 \\
\hline Corydalis turtschaninovii Besser (Tuber) & $\begin{array}{l}\text { Methanolic extract of the alkaloidal } \\
\text { component (10-200 } \mu \mathrm{g} / \mathrm{mL}) \\
\text { containing dehydrocorydaline }\end{array}$ & Inhibiting AR activity. & Kubo et al., 1994 \\
\hline Curcuma longa L. (Rhizome) & Aqueous extract, $25-300 \mu \mathrm{g} / \mathrm{mL}$ & $\begin{array}{l}\text { Prevents in vitro cataract via AR inhibitory } \\
\text { activity. }\end{array}$ & Halder et al., 2003 \\
\hline $\begin{array}{l}\text { Dendrobium chrysotoxum Lindl. } \\
\text { (Stems) }\end{array}$ & Gigantol & Inhibition of AR and AR gene expression. & Wu et al., 2017 \\
\hline $\begin{array}{l}\text { Dendrobium aurantiacum (F. Muell.) F. } \\
\text { Muell. var. denneanumis (Kerr) Z.H.Tsi } \\
\text { (Stems) }\end{array}$ & Gigantol & $\begin{array}{l}\text { Attenuation in increase of AR, inducible } \\
\text { nitric oxide synthase (iNOS) expression and } \\
\text { opacification of rat lenses. }\end{array}$ & Fang et al., 2015 \\
\hline $\begin{array}{l}\text { Eclipta prostrata (L.) L. [Syn. Eclipta } \\
\text { alba (L.) Hassk.] (Whole plant) }\end{array}$ & Ethanolic extract (flavonoids) & Inhibition of AR & Jaiswal et al., 2012 \\
\hline Erigeron annuus (L.) Pers. (Flowers) & Isolated phenolic compounds & $\begin{array}{l}\text { Inhibition of cataract via inhibiting protein } \\
\text { glycation and AR in rat lens. }\end{array}$ & Jang et al., 2008 \\
\hline $\begin{array}{l}\text { Eugenia cordata (Sw.) DC.var. sintenisii } \\
\text { (Kiaersk.) Krug \& Urb. (Not mentioned) }\end{array}$ & Ethanolic extract & Inhibition of AR. & Guzman and Guerrero, 2005 \\
\hline Ficus glomerata L. (Fruits) & $\begin{array}{l}\text { Sequential water, ethanol, and } \\
\text { chloroform extracts }\end{array}$ & $\begin{array}{l}\text { AR inhibition and maintaining of lens } \\
\text { opacity. }\end{array}$ & Gacche and Dhole, 2011b \\
\hline $\begin{array}{l}\text { Marsdenia sylvestris (Retz.) P.I.Forst. } \\
\text { [Syn. Gymnema sylvestre (Retz.) R. Br.] } \\
\text { (Leaves) }\end{array}$ & The polyol Conduritol A & Inhibition of AR. & Miyatake et al., 1994 \\
\hline Thymus vulgaris L. (Leaves) & $\begin{array}{l}\text { Methanolic extract and isolated } \\
\text { compounds (Eriodictyol) }\end{array}$ & $\begin{array}{l}\text { Suppression of the advanced glycation end } \\
\text { products levels and fructosamines of } \\
\text { albumin. }\end{array}$ & Morimitsu et al., 1995 \\
\hline Genistein & Genistein & Increase connexin (Cx) 43 expression. & Huang et al., 2007 \\
\hline Zingiber officinale Roscoe (Rhizomes) & Powder & Suppressing lens galactitol accumulation. & Saraswat et al., 2010 \\
\hline $\begin{array}{l}\text { Hydrocotyle bonariensis Comm. ex } \\
\text { Lam. (Leaves) }\end{array}$ & $\begin{array}{l}\text { Aqueous extract, } 500 \text { and } \\
1,000 \mathrm{mg} / \mathrm{kg}\end{array}$ & $\begin{array}{l}\text { Reduction in lens protein insolubilization, } \\
\text { lens peroxidation and increase in the } \\
\text { antioxidant status of the lens. }\end{array}$ & Ajani et al., 2009 \\
\hline
\end{tabular}


TABLE 3 | Continued

\begin{tabular}{ll}
\hline $\begin{array}{l}\text { Plant (with part used)/natural } \\
\text { product }\end{array}$ & \multicolumn{1}{c}{$\begin{array}{c}\text { Doses, concentrations and } \\
\text { characteristics of extracts }\end{array}$} \\
\hline $\begin{array}{l}\text { Justicia adhatoda L. (Syn. Adhatoda } \\
\text { vasica Nees.) (Procured extract) }\end{array}$ & $\begin{array}{l}\text { Sequential water, ethanol and chloroform } \\
\text { extracts } \\
\text { KIOM-79 }\end{array}$ \\
& $\begin{array}{l}\text { (80\% ethanol extract of parched } \\
\text { Puerariae Radix, gingered). (Magnoliae } \\
\text { cortex, Glycyrrhizae Radix and }\end{array}$ \\
& Euphorbiae Radix) (Magnolia officinalis, \\
& $\begin{array}{l}\text { Pueraria lobata, Glycyrrhiza uralensis, } \\
\text { Euphorbia pekinensis) }(0-1,000 \mu \mathrm{g} / \mathrm{mL})\end{array}$ \\
& Isolated scopoletin and tiliroside
\end{tabular}

C. Cheng (Flower buds)

Mangifera indica L.

Miyamayomena koraiensis (Nakai) Kitam. (Syn. Aster koraiensis Nakai) (Korean starwort) (Aerial part)

Momordica charantia L. (Fruits)

Ocimum tenuiflorum L. (Syn. Ocimum sanctum L.) (Leaves)

Peonidin-3-glucoside

Phyllanthus emblica L. (Syn. Emblica

officinalis Gaertn.) (Fruits)

Pterocarpus marsupium Roxb. (Bark)

Pueraria montana (Lour.) Merr. var. lobata (Willd.) Sanjappa \& Pradeep. (Roots)

Rutin

Silybin

Silybum marianum (L.) Gaertn. (Seeds)

Syzygium cumini (L.) Skeels (Syn. Eugenia jambolana Lam.) (Kernels) Syzygium nervosum A.Cunn. ex DC. [Cleistocalyx operculatus (Roxb.) Merr. \& L.M.Perry] (Dried flower buds) Tephrosia purpurea (L.) Pers. (Whole plant)

Theobroma cacao L. (Cacao liquor)

Tinospora sinensis (Lour.) Merr. [Syn. Tinospora cordifolia (Willd.) Miers] (Procured stem extract)

Triphala Ghrita

Vitamin K

Zea mays L. (Seed)

Zingiber officinale Roscoe (Rhizomes)

\section{Ethanolic extract \\ Extract of 100 and $200 \mathrm{mg} / \mathrm{kg}$}

Aqueous and ethanolic extracts, 200 and $400 \mathrm{mg} / \mathrm{kg}$

Aqueous extract, $25-300 \mu \mathrm{g} / \mathrm{mL}$

Peonidin-3-glucoside

Isolated $\beta$-glucogallin $(0-40 \mu \mathrm{M})$

Aqueous extract, $2 \mathrm{~g} / \mathrm{kg}$

Puerariafuran isolated from methanoilc extract

Rutin (10-100 $\mu \mathrm{M})$

Silybin, $231 \mathrm{mg} /$ day for 4 weeks

Aqueous and ethanolic extracts, 200 and $400 \mathrm{mg} / \mathrm{kg}$

Aqueous extract, $500 \mathrm{mg} / \mathrm{kg}$ bw/day

Flavonoid rich fraction, $40 \mathrm{mg} / \mathrm{kg} /$ day, p.o, whole plant

Crude polyphenol fraction $(0.5 \%$ with diet) (Cyanidin)

Aqueous and ethanolic extracts, 200 and $400 \mathrm{mg} / \mathrm{kg}$

It's an Ayurvedic formulation containing gallic acid

Vitamin K

Hydroalcoholic extract, 2, 10, and $50 \mathrm{mg} / \mathrm{mL}$

Powder
Silymarin 200 mg/kg/d, from extract

\section{Suggested/possible} mechanism of action

AR inhibition and antioxidant action.

AR inhibition. KIOM-79, an Inhibitor of AGEs-Protein Cross-linking, Prevents Progression of Nephropathy in Zucker Diabetic Fatty Rats.

Inhibition of rat lens aldose reductase (RLAR) activity; ex vivo cataractogenesis of rat lenses induced by xylose was inhibited by scopoletin. AR inhibition and antioxidant activity.

Delay in the progression of lens opacification during the early diabetic cataractogenesis.

Prevention of experimental diabetic cataract through reduction of plasma glucose levels.

Prevents in vitro cataract by virtue of its aldose reductase inhibitory activity.

Inhibits lens AR.

Inhibition of AKR1B1.

Decreased opacity index.

Inhibition of rat lens AR.

Inhibits advanced glycation end products formation by prevention of dicarbonyls formation.

Reductions in the erythrocytic sorbitol level which lead to formation of glycation end products.

Antioxidative activity and increase in lens GSH and decrease in lipid peroxides (LPO) levels.

Significant reduction of plasma glucose.

Indirect antihyperglycemic effect, decreases the levels of glucose, sorbitol, and fructose in diabetic rat lenses.

AR enzyme inhibition and anti-oxidant activity.

Inhibits lens AR.

Prevention of retinal oxidative stress, restoration of antioxidant enzyme levels and reduction in the angiogenic markers, vascular endothelial growth factor (VEGF) and protein kinase $\mathrm{C}(\mathrm{PKC})$ that are increased in diabetic retina.

Delay in the onset and progression of galactose induced cataract through antioxidant activity.

Lens $\mathrm{Ca}^{2+}$ homeostasis modulation and inhibition of osmotic and oxidative stress. Decline in oxidative stress and inhibition of aldose reductase.

Reduction in the carbonyl stress, inhibition of osmotic stress by reduction in the activity of the polyol pathway, oxidative stress prevention.
References

Gacche and Dhole, 2011a

Kim et al., $2011 b$

Lee et al., 2010

Guzmán and Guerrero, 2005

Kim et al., 2009

Rathi et al., 2002

Halder et al., 2003

Morimitsu et al., 2002

Puppala et al., 2012

Vats et al., 2004

Kim et al., 2010

Muthenna et al., 2012

Zhang et al., 1995

Fallah Huseini et al., 2009

Rathi et al., 2002

Mai et al., 2010

Bhadada et al., 2016b

Osakabe et al., 2004

Rathi et al., 2002;

Rajalakshmi et al., 2009;

Agrawal et al., 2012

Mahajan et al., 2011

Sai Varsha et al., 2014

Thiraphatthanavong et al., 2014

Saraswat et al., 2010 
TABLE 4 | Medicinal plants/natural products used against cataract on advanced glycation end products (AGE)- BSA cross-linking inhibition assay and lens aldose reductase activity models and possible mechanisms of action.

\begin{tabular}{|c|c|c|c|}
\hline $\begin{array}{l}\text { Plant (with part used)/natural } \\
\text { product }\end{array}$ & Doses, concentrations and characteristics of extracts & $\begin{array}{l}\text { Suggested/possible } \\
\text { mechanism of action }\end{array}$ & References \\
\hline
\end{tabular}

Caesalpinia digyna Rottler (Roots)

Cinnamomum verum J.Presl (Bark)

Cornus officinalis Siebold \& Zucc.

(Seeds)

Erigeron annuus (L.) Pers. (Leaves and stems)

Flavonoids

Hybanthus enneaspermus (L.) F.Muell. (Whole plant)

Magnolia biondii Pamp. [Syn. Magnolia fargesii (Finet \& Gagnep.) W.C.Cheng] (Flower buds)

Onoclea orientalis (Hook.) Hook. (Syn. Matteuccia orientalis Trev.) (Rhizomes) Morinda citrifolia L. (Fruits)

Onoclea orientalis (Hook.) Hook. (Syn. Matteuccia orientalis Trev.) (Rhizomes) Platycodon grandiflorus (Jacq.) A.DC. (Flowers)

Salvia miltiorrhiza Bunge (Roots)
Alcoholic extract at an increasing concentration between 0 and $200 \mu \mathrm{g} / \mathrm{mL}\left(\mathrm{IC}_{50} 46.29 \pm 11.17 \mu \mathrm{g} / \mathrm{mL}\right)$

Ethanolic extract fractions containing Procyanidin-B2, $1-3 \mathrm{mg}$

EtOAc-soluble fraction (Galloyl glucoses)

3,5-Di-O-caffeoyl-epi-quinic acid isolated from methanolic fraction, $5 \mu \mathrm{M}$

Chrysin, apigenin, and baicalein

Different fractions from ethanolic extract, $0-300 \mu \mathrm{g} / \mathrm{mL}$

Isolated scopoletin and tiliroside

Isolated compound Matteuorienate A, Matteuorienate B from the methanolic extract

Sequential water, ethanol, and chloroform extracts

Isolated compound from the methanolic extract Matteuorienate $\mathrm{C}$

Isolated compounds from ethyl acetate soluble fractions [apigenin, luteolin, luteolin-7-O- $\beta$-D-glucopyranoside, luteolin-7-O-(6"-O-acetyl)- $\beta$-D-glucopyranoside, apigenin-7-O- $\beta$-D-glucopyranoside,

apigenin-7-O-( $6^{\prime \prime}-O$-acetyl)- $\beta$-D-glucopyranoside, isorhamnetin-3-Oneohesperidoside, 4-O-caffeoylquinic acid, chlorogenic acid methyl ester,

4-O- $\beta$-D-glucopyranosyl caffeic acid]

Constituents of methanolic extract Danshenol A Dansheno B, (-)-Danshexinkun A, Dihydrotanshinone I, Tanshinone IIA
AR inhibition and antioxidant action.

Kumar et al., 2011

AGE inhibition of eye lens proteins under in vitro conditions and

Muthenna et al., 2013 inhibition of the formation of glycosylated hemoglobin in human blood in ex vivo conditions.

Inhibition of formation of AGE, AGE- Lee et al., 2011 BSA cross-linking, and RLAR. Inhibition of AGEs, AGEs-BSA cross-linking to collagen, RLAR formation, and prevention of lenses opacification.

Inhibition of glycation, glycation induced lens opacity, AGEs, AR and lens protein aggregation. Not clearly described. Jang et al., 2010b

RLAR inhibition.

Lee et al., 2010

AR inhibition.

Kadota et al., 1994

AR inhibition and free radical scavenging activity.

AR inhibition.

Gacche and

Dhole, 2011b

Basnet et al., 1995

Substantial inhibition of AGEs formation and RLAR.
Watanabe et al., 2013), Sudan (Khalid et al., 2012), Tanzania (Maregesi et al., 2016), South Africa (Pendota et al., 2008), and many other regions of the world.

The literature analysis revealed that the sugar-induced or diabetic cataract models were the highest used models which were applied for the evaluation of around $39.84 \%$ of the plants/natural products. It was followed by selenite/sodium selenite induced cataract which is another common model of evaluation of cataract, and it accounts for around $36.71 \%$ of the plants/natural products. AGE-BSA crosslinking inhibition assay was used for the evaluation of $10.93 \%$, and hydrogen peroxide and naphthalene induced cataract was account for evaluation of around $9.38 \%$ of the plants (Figure 3). In most of the cases especially for the diabetic cataract models, it was found that different antioxidant parameters like soluble protein, reduced glutathione, superoxide dismutase, lipid peroxidation were used (Bhadada et al., 2016b). Inhibition of AR was found as the most common hypothesis in these models (Bhadada et al., 2016b). Uses of in silico studies were also found common in some studies to explore the binding mode of the phytochemicals with the aldose reductase enzyme (Bhadada et al., 2016b; Patil et al., 2016).

In most of the studies, rats or rat pups lens were utilized as the model (Bhadada et al., 2016b; El Okda et al., 2016; Ferlemi et al., 2016; Sreelakshmi and Abraham, 2016) and in some cases fresh goat eyeballs were also used (Patil et al., 2016). In vitro studies were also utilized in large number of experiments. In some studies lens crystalline turbidity assay was used by estimation of lens protein turbidity using homogenized decapsulated porcine lenses which were procured from the local slaughterhouses in some cases (Ferlemi et al., 2016; Liao et al., 2016). Some other important factors in cataractogenesis like UV radiation was also used by researchers, and it was also proposed that some compounds can protect $\gamma$-crystallin from UV radiation damage and can act as potential anticataract agents (Liao et al., 2016).

Many of the mentioned plants showed potent anticataract activity in in vitro and in vivo models. Vitex negundo and Vitis 
<smiles>O=c1cc(-c2ccc(O)cc2)oc2c(C(O)CC(O)C3OOO3)c(O)cc(O)c12</smiles><smiles>O=c1c(O)c(-c2cc(O)c(O)c(O)c2)oc2cc(O)cc(O)c12</smiles>

myricetin<smiles>COc1cc(/C=C/C(=O)CC(=O)/C=C/c2ccc(O)c(OC)c2)ccc1O</smiles><smiles>O=C1C[C@H](c2ccc(O)c(O)c2)Oc2cc(O)cc(O)c21</smiles><smiles>O=c1cc(-c2ccc(O)cc2)oc2cc(O)cc(O)c12</smiles>
apigenin<smiles>O=c1oc2c(O)c(O)cc3c(=O)oc4c(O)c(O)cc1c4c23</smiles>

ellagic acid<smiles>O=c1cc(-c2ccc(O)c(O)c2)oc2cc(O)cc(O)c12</smiles><smiles>COc1ccc(C2c3c(O)cccc3C=CC2C=O)c(OC)c1</smiles><smiles>O=c1c(-c2ccc(O)cc2)coc2cc(O)cc(O)c12</smiles><smiles>O=C(O)C1(O)CCC(O)(C(=O)O)C(C=Cc2ccc(O)c(O)c2)C1O</smiles>

FIGURE 2 | Chemical structures of some of the relevant natural products discussed in the context of cataract treatment.

vinifera were the plants in which sufficient preclinical studies were conducted and they may be of potential clinical use. It is also interesting that Vitex negundo was also used in the folk medicine in India (Kulkarni et al., 2008). The genus Ocimum was also one such genus which is utilized in folk medicine and was scientifically validated for its anticataract potential. Some other interesting findings were the use of Pleurotus ostreatus extract that prevented cataract in $75 \%$ of the tested rats (Isai et al., 2009). In a clinical study, although not directly against cataract, silybin improved the peripheral nerve conduction velocity and was reported as an effective aldose reductase inhibitor that can improve the disorder of polyol pathway in non-insulin dependent diabetes patients and prevent chronic complications of diabetes (Zhang et al., 1995) like cataract.

The detailed list of medicinal plants used in the management of cataract as reported in many ethnopharmacological surveys is given in Table 6. Singh et al. (2012) had also listed the medicinal plants used in management of cataract, however, the mechanistic insight was not performed and plants used in the management of cataract available till 2011 were covered (Singh et al., 2012).

It was found that most of the surveys were conducted in different developing countries like Bangladesh, Chile,
India, Nepal, and Tanzania (see Figure 4). Apart from the ethnobotanical surveys, several plants used in traditional medicine systems like Ayurveda were also found beneficial for cataract. One such good example of use of Ayurvedic formulation against cataract is the use of Triphala which showed good effect against cataract in in vitro and in vivo (Gupta et al., 2010a; Mahajan et al., 2011) studies and also was evaluated clinically and showed promising results (Bhati and Manjusha, 2015), however, more clinical studies are required involving larger patients for better scientific evidences. Plants used in Ayurveda like Momordica charantia, Eugenia jambolana, Pterocarpus marsupium, and Trigonella foenum-graecum prevented cataract development when observed in alloxan diabetic cataract model (Rathi et al., 2002; Vats et al., 2004).

Although, many plants have been utilized in various folklore medical practices, most of them are not scientifically validated. Moreover, some of these traditional practices may be harmful for the eyes as well. For instance, use of latex/sap of some Euphorbiaceae plants like Euphorbia hirta and Croton caudatus can be dangerous for eyes rather being beneficial. Moreover, sufficient care is obligatory while using the herbal medication for any of the eye diseases, as there is a case study that showed 
TABLE 5 | Medicinal plants/natural products used against cataract on hydrogen peroxide- and naphthalene induced cataract and other miscellaneous models and possible mechanisms of action.

\begin{tabular}{|c|c|c|c|}
\hline $\begin{array}{l}\text { Plant (with part used)/ } \\
\text { natural product }\end{array}$ & $\begin{array}{l}\text { Doses, concentrations and } \\
\text { characteristics of extracts }\end{array}$ & Suggested/possible mechanism of action & References \\
\hline $\begin{array}{l}\text { Abies pindrow (Royle ex } \\
\text { D.Don) Royle (Leaves) }\end{array}$ & Aqueous extract (5-20 mg/mL) & Inhibition of free radical generation. & Dubey et al., 2015b \\
\hline Acorus calamus L. (Roots) & Methanolic extract and $\beta$-asarone & $\begin{array}{l}\text { Significantly retarded experimental hydrogen peroxide } \\
\text { induced cataractogenesis. }\end{array}$ & Kumar and Singh, 2011 \\
\hline $\begin{array}{l}\text { Cistanche deserticola Y.C.Ma } \\
\text { and SkQ1 (Stolons) }\end{array}$ & Fraction & $\begin{array}{l}\text { Increase of the lens protein solubility and destroying of large } \\
\text { protein aggregates, antioxidant action leads to elevation of } \\
\text { tryptophan and kynurenine levels in the lens. }\end{array}$ & Snytnikova et al., 2012 \\
\hline $\begin{array}{l}\text { Elaeagnus rhamnoides (L.) } \\
\text { A.Nelson (Syn. Hippophae } \\
\text { rhamnoides L.) (Leaves) }\end{array}$ & Aqueous extract, $100-1,000 \mu \mathrm{g} / \mathrm{mL}$ & $\begin{array}{l}\text { Regulation of oxidative stress and promotion of antioxidant } \\
\text { systems. }\end{array}$ & Dubey et al., 2016 \\
\hline Erythrina stricta Roxb. (Leaves) & $\begin{array}{l}\text { Hydromethanolic extract (fractions), } \\
200 \mathrm{mg} / \mathrm{kg}\end{array}$ & $\begin{array}{l}\text { Antioxidant activity, prevented the peroxidative damage } \\
\text { caused by naphthalene. }\end{array}$ & $\begin{array}{l}\text { Umamaheswari et al., } \\
2010\end{array}$ \\
\hline Foeniculum vulgare Mill. (Fruits) & $\begin{array}{l}\text { Petroleum ether fraction, } 10 \text { mg/kg, } \\
\text { twice daily }\end{array}$ & AR reduction and antioxidant action. & Dongare et al., 2012 \\
\hline L-arginine & L-arginine & Blocking of carbonyl stress in the lens. & Fan et al., 2011 \\
\hline $\begin{array}{l}\text { Luffa cylindrica (L.) M.Roem. } \\
\text { (Fruits) }\end{array}$ & Standardized extract, $5-30 \mu \mathrm{g} / \mathrm{mL}$ & Protection of lens proteins from oxidative damage. & Dubey et al., $2015 a$ \\
\hline Nigella sativa L. (Seeds) & Oil & Inhibiting of RNS generation, antioxidant action, and FRSA. & $\begin{array}{l}\text { Taysi et al., 2015; } \\
\text { Demir et al., } 2016\end{array}$ \\
\hline $\begin{array}{l}\text { Ocimum tenuiflorum L. } \\
\text { (Leaves) }\end{array}$ & Aqueous extract, $150 \mu \mathrm{g} / \mathrm{mL}$ & FRSA. & Halder et al., 2009 \\
\hline $\begin{array}{l}\text { Pueraria montana var. lobata } \\
\text { (Will) Sanjappa \& Pradeep }\end{array}$ & $\begin{array}{l}\text { Puerariafuran isolated from methanolic } \\
\text { extract }\end{array}$ & $\begin{array}{l}\text { Inhibition of AR, xylose-induced lens opacity, and the } \\
\text { oxidation in lenses. }\end{array}$ & Kim et al., 2010 \\
\hline
\end{tabular}

[Syn. Pueraria lobata (Willd.)

Ohwi] (Roots)

Vitis vinifera L. (Seed)

Extract constituting of $95 \%$ proanthocyanidins
Attenuates cell signaling, cell migration and inflammation, prevention of oxidative stress, inhibition of $\mathrm{H}_{2} \mathrm{O}_{2}$-induced phosphorylation of the p38 and c-Jun $\mathrm{N}$-terminal kinase.
Jia et al., 2011

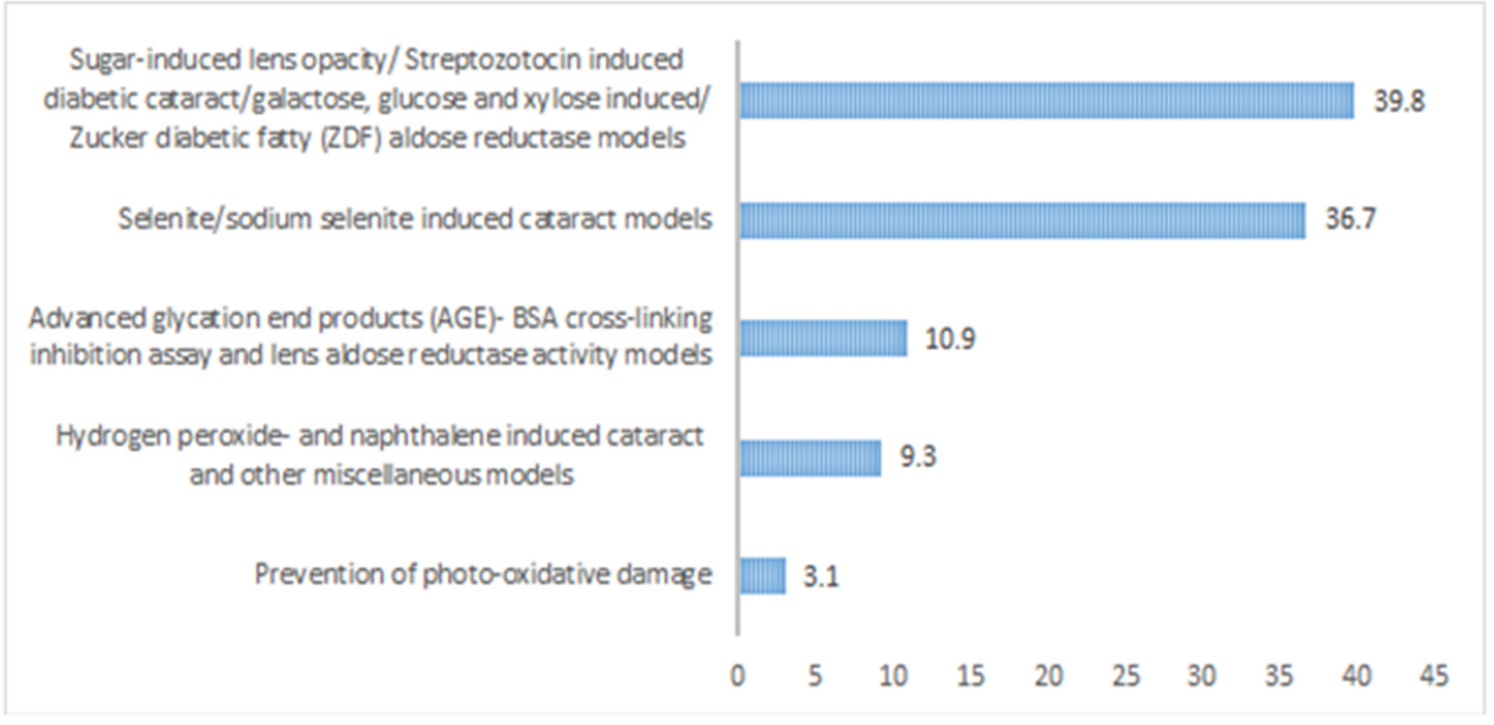

FIGURE 3 | Percentage of different models used for evaluation of anticataract activity of plants/natural products.

that cataract or development of cataract was aggravated after treatment with some unrevealed herbal medication in a 11 years old patient with atopic dermatitis (Kang et al., 2008).
This survey reveals that selenite/sodium selenite induced cataracts was the preferred model in studies with natural products used against cataract, followed by sugar-induced 
TABLE 6 | Medicinal plants reported globally by different ethnopharmacology/ethnobotanical surveys to be used in the treatment of cataract.

\begin{tabular}{|c|c|c|c|c|}
\hline Plant & $\begin{array}{l}\text { Formulations and mode of } \\
\text { administration }\end{array}$ & Major chemical constituents & Country & References \\
\hline $\begin{array}{l}\text { Abrus precatorius L. } \\
\text { (Fabaceae) }\end{array}$ & $\begin{array}{l}\text { Fresh leaves are squeezed and juice is } \\
\text { used as eye drops }\end{array}$ & $\begin{array}{l}\text { Abrine; trigonelline; abruslactone A; hemiphloin } \\
\text { and abrusin }\end{array}$ & India/Tanzania & $\begin{array}{l}\text { Ragasa et al., 2013; } \\
\text { Garaniya and Bapodra, } \\
\text { 2014; Maregesi et al., } 2016\end{array}$ \\
\hline $\begin{array}{l}\text { Aloe vera (L.) Burm. f. } \\
\text { (Asphodelaceae) }\end{array}$ & $\begin{array}{l}\text { One drop of leaf juice twice a day is } \\
\text { used as eye drop }\end{array}$ & Anthraquinones; aloe emodin and chrysophanol & Tanzania & $\begin{array}{l}\text { Lee et al., 2013; Maregesi } \\
\text { et al., } 2017\end{array}$ \\
\hline $\begin{array}{l}\text { Barleria prionitis L. } \\
\text { (Acanthaceae) }\end{array}$ & Leaf juice is used & $\begin{array}{l}\text { Phenylethanoid glycoside; barlerinoside along } \\
\text { with six known iridoid glycosides }\end{array}$ & Sri Lanka & $\begin{array}{l}\text { Jaiswal et al., 2014; } \\
\text { Rajamanoharan, } 2014\end{array}$ \\
\hline $\begin{array}{l}\text { Bidens pilosa L. } \\
\text { (Asteraceae) }\end{array}$ & $\begin{array}{l}\text { Juice of fresh leaves is used as eye } \\
\text { drops. }\end{array}$ & $\begin{array}{l}\text { Phenylheptatriyne; linoleic acid; linolenic acid; } \\
\text { friedelin and friedelan-3 beta-ol }\end{array}$ & Tanzania & $\begin{array}{l}\text { Geissberger and Sequin, } \\
\text { 1991; Maregesi et al., } 2016\end{array}$ \\
\hline $\begin{array}{l}\text { Boquila trifoliolata (DC.) } \\
\text { Decne. } \\
\text { (Lardizabalaceae) }\end{array}$ & $\begin{array}{l}\text { Fresh leaves are squeezed and the } \\
\text { juice is utilized as eye drops. }\end{array}$ & Oleanolic acid & Chile & $\begin{array}{l}\text { Gusinde, 1936a,b; Silva } \\
\text { and Stück, } 1962\end{array}$ \\
\hline $\begin{array}{l}\text { Breynia vitis-idaea } \\
\text { (Burm.f.) C.E.C.Fisch. } \\
\text { (Syn. Breynia } \\
\text { rhamnoides M. Arg.) } \\
\text { (Euphorbiaceae) }\end{array}$ & $\begin{array}{l}\text { Stem exudate is put in the eyes for } \\
2-3 \text { days in the morning }\end{array}$ & Breynin and breyniaionoside $\mathrm{E}$ & India & $\begin{array}{l}\text { Parinitha et al., 2004; } \\
\text { Meng et al., } 2010\end{array}$ \\
\hline $\begin{array}{l}\text { Byttneria herbacea } \\
\text { Roxb. (Malvaceae) }\end{array}$ & Root paste is used & Not described & India & Biswas et al., 2016 \\
\hline $\begin{array}{l}\text { Chusquea quila Kunth } \\
\text { (Poaceae) }\end{array}$ & $\begin{array}{l}\text { New stems are heated and the juice of } \\
\text { the stem is received in a vessel and } \\
\text { mixed with breast milk and Oxalis rosea }\end{array}$ & Holocellulose; lignin and $\alpha$-Cellulose & Chile & $\begin{array}{l}\text { Gusinde, 1936a,b; Oliveira } \\
\text { et al., } 2016\end{array}$ \\
\hline $\begin{array}{l}\text { Citrus limon (L.) Osbeck } \\
\text { (Rutaceae) }\end{array}$ & $\begin{array}{l}\text { Salted lemon juice is used as eye } \\
\text { drops. }\end{array}$ & Linalool; $\alpha$-humulene; $\alpha$-pinene and limonene & Tanzania & $\begin{array}{l}\text { Golmakani and Moayyedi, } \\
\text { 2015; Maregesi et al., } 2017\end{array}$ \\
\hline $\begin{array}{l}\text { Coccinia grandis (L.) } \\
\text { Voigt (Cucurbitaceae) }\end{array}$ & $\begin{array}{l}\text { Juice of the stems is dripped into the } \\
\text { eyes to treat cataract. }\end{array}$ & Cephalandrine A and cephalandrine B & Nepal & $\begin{array}{l}\text { Gewali, 2011; Manandhar, } \\
2002\end{array}$ \\
\hline $\begin{array}{l}\text { Colocasia sp. } \\
\text { (Araceae) }\end{array}$ & $\begin{array}{l}\text { Leaves are cooked and eaten for } \\
2-4 \text { weeks or till curing. }\end{array}$ & Flavonoids; $\beta$-sitosterol and steroids & Bangladesh & $\begin{array}{l}\text { Prajapati et al., 2011; Linky } \\
\text { et al., } 2015\end{array}$ \\
\hline Commiphora edulis & Fresh latex which was produced on & Not described & Tanzania & Maregesi et al., 2016 \\
\hline
\end{tabular}

(Klotzsch) Engl. detachment of leaf is applied daily until (Burseraceae) recovery.

Croton caudatus Gum/sap is mixed with mustard oil and

Geisel. (Euphorbiaceae)

Croton bonplandianus Baill. (Euphorbiaceae)

Diplolepis geminiflora (Decne.) Liede \& Rapini (Apocynaceae)

Dolichos trilobus L. (Leguminosae)

Duchesnea indica (Jacks.) Focke

(Rosaceae)

Eryngium paniculatum Cav. \& Dombey ex F. Delaroche (Apiaceae) Erythrina indica Lam. (Papilionaceae)

Euphorbia hirta L. (Euphorbiaceae)
Young stem juice is used as eye drops

The latex secreted when cutting a

branch is applied over the eyes

Leaf juice is boiled, cooled and applied.

Leaf juice is applied

Decoction of the root is put in the eyes

Juice is put drop-wise in the affected eye

Fresh latex obtained from detached leaves, three drops used for three times a day
Bis(2,3-dihydroxypropyl) nonanedioate; 12-O( $\alpha$-methyl)butyrylphorbol-13-decanoate; 12-Otiglylphorbol-13-decanoate; (9S,10R,11E,13R)9,10,13-trihydroxyoctadec-11-enoic acid; methyl $(9 S, 10 R, 11 E, 13 R)-9,10,13-$ trihydroxyoctadec-11-enoate; $4(1 \mathrm{H})$ quinolinone and 5-hydroxy-2-pyridinemethanol Phorbol esters

Not described

Doliroside A; phenols and tannins

Ellagitannins; ellagic acid glycosides; hydroxybenzoic acid; ellagic acid; hydroxycinnamic acid derivatives, and flavonols

(E)-anethole; $\alpha$-pinene; (-)-2,4,4-Trimethyl-3formyl-2,5-cyclohexadienyl angelate

Lectin

Afzelin; quercitrin; myricitrin; rutin; quercetin; euphorbin-A; euphorbin-B; euphorbin-C and euphorbin-D
Linky et al., 2015; Su et al., 2016

India

Phillipson, 1995; Islam et al., 2010; Vashistha and Kaur, 2013

Chile

Gusinde, 1936a,b

Tanzania Hedberg et al., 1983; Bisby, 1994

India Kapkoti et al., 2011; Zhu et al., 2015

Chile

Gusinde, 1936a,b; Cobos et al., 2002

India

Konozy et al., 2002; Parinitha et al., 2004; Biswas et al., 2016

Tanzania Kumar et al., 2010; Maregesi et al., 2016, 2017 
TABLE 6 | Continued

\begin{tabular}{|c|c|c|c|c|}
\hline Plant & $\begin{array}{l}\text { Formulations and mode of } \\
\text { administration }\end{array}$ & Major chemical constituents & Country & References \\
\hline $\begin{array}{l}\text { Fascicularia bicolor } \\
\text { (Ruiz \& Pav.) Mez } \\
\text { (Bromeliaceae) }\end{array}$ & The juice of the young plant parts & Not described & Chile & Gusinde, 1936a,b \\
\hline $\begin{array}{l}\text { Ficus benghalensis L. } \\
\text { (Moraceae) }\end{array}$ & Milky juice is used & $\begin{array}{l}\text { Alkaloids; glycosides, terpenoids; flavonoids; and } \\
\text { tannins }\end{array}$ & Nepal & $\begin{array}{l}\text { Acharya and Pokhrel, 2006; } \\
\text { Ogunlowo et al., } 2013\end{array}$ \\
\hline $\begin{array}{l}\text { Geranium core-core } \\
\text { Steud. (Geraniaceae) }\end{array}$ & Powdered roots are placed on the eyes & $\begin{array}{l}\text { Hexadecanoic acid; hexahydrofarnesyl acetone and } \\
\text { tetracosane }\end{array}$ & Chile & $\begin{array}{l}\text { Gusinde, 1936a,b; } \\
\text { Radulovic et al., } 2011\end{array}$ \\
\hline $\begin{array}{l}\text { Ludwigia hyssopifolia } \\
\text { (G.Don) Exell } \\
\text { (Onagraceae) }\end{array}$ & $\begin{array}{l}\text { Juice of this plant along with Ocimum } \\
\text { americanum L.- Camphor type ( } 2 \text { drops } \\
\text { thrice daily for } 7-8 \text { days) is given in the } \\
\text { eye as a drop. }\end{array}$ & Piperine & Bangladesh & $\begin{array}{l}\text { Yusuf et al., 2006; Das } \\
\text { et al., } 2007\end{array}$ \\
\hline $\begin{array}{l}\text { Marchantia polymorpha } \\
\text { L. (Marchantiaceae) }\end{array}$ & $\begin{array}{l}\text { Ointment of the crushed plant is } \\
\text { prepared, applying it to the eyes }\end{array}$ & 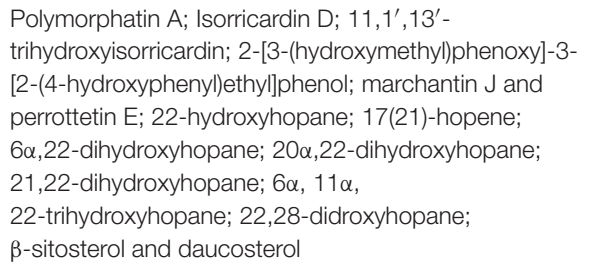 & Chile & $\begin{array}{l}\text { Gusinde, 1936a,b; Fang } \\
\text { et al., 2007, } 2008\end{array}$ \\
\hline $\begin{array}{l}\text { Microglossa pyrifolia } \\
\text { (Lam.) Kuntze } \\
\text { (Asteraceae) }\end{array}$ & Root juice is used as eye drops & $\begin{array}{l}\alpha \text {-Humulene and } \alpha \text {-pinene, } \Delta^{3} \text {-carene, }(E) \text { - } \beta \text {-ocimene } \\
\text { and germacrene } D\end{array}$ & Tanzania & $\begin{array}{l}\text { Hedberg et al., 1983; Boti } \\
\text { et al., } 2007\end{array}$ \\
\hline $\begin{array}{l}\text { Nepenthes khasiana } \\
\text { Hook.f. (Nepenthaceae) }\end{array}$ & Not described & $\begin{array}{l}\text { Droserone; 5-O-methyldroserone and } \\
\text { naphthoquinones }\end{array}$ & India & $\begin{array}{l}\text { Eilenberg et al., 2010; Dhal } \\
\text { et al., } 2011\end{array}$ \\
\hline $\begin{array}{l}\text { Nephrolepis biserrata } \\
\text { (Sw.) Schott } \\
\text { (Nephrolepidaceae) }\end{array}$ & Rhizome is scrubbed in the eyes & $\begin{array}{l}1 \beta, 11 \alpha \text {-Diacetoxy-11,12-epoxydrim-7-ene; } \\
1 \beta, 6 \alpha, 11 \alpha \text {-triacetoxy-11,12-epoxydrim-7-ene; } \\
1 \beta, 3 \beta, 11 \alpha \text {-triacetoxy-11,12-epoxydrim-7-ene; } \\
9(11) \text {-fernene }\end{array}$ & Chile & $\begin{array}{l}\text { Gusinde, 1936a,b; Bottari } \\
\text { et al., 1972; Siems et al., } \\
1996\end{array}$ \\
\hline $\begin{array}{l}\text { Ocimum americanum } \\
\text { L. (Lamiaceae) }\end{array}$ & $\begin{array}{l}\text { Juice of } O \text {. americanum with Ludwigia } \\
\text { hyssopifolia (two drops thrice daily for } \\
7-8 \text { days) is given in the eye as a drop }\end{array}$ & $\begin{array}{l}\text { 1,8-Cineol; camphor; } \alpha \text {-pinene and } \\
\text { trans- } \alpha \text {-bergamotene }\end{array}$ & Bangladesh & $\begin{array}{l}\text { Yusuf et al., 2006; Bayala } \\
\text { et al., } 2014\end{array}$ \\
\hline $\begin{array}{l}\text { Oenothera acaulis Cav. } \\
\text { (Onagraceae) }\end{array}$ & Stem juice is given in the eye as a drop. & Not described & Chile & Gusinde, 1936a,b \\
\hline $\begin{array}{l}\text { Oxalis corniculata L. } \\
\text { (Oxalidaceae) }\end{array}$ & Leaf juice is used. & $\begin{array}{l}\text { Flavonoids; iso-vitexin; } \\
\text { vitexin-2"-O- } \beta-D-\text { glucopyranoside; oleic acid; palmitic } \\
\text { acid; linoleic acid; linolenic acid and stearic acid }\end{array}$ & India & $\begin{array}{l}\text { Badwaik et al., 2011; } \\
\text { Vashistha and Kaur, } 2013\end{array}$ \\
\hline $\begin{array}{l}\text { Oxalis rosea Jacq. } \\
\text { (Oxalidaceae) }\end{array}$ & Plant material scrubbed in the eye. & $\begin{array}{l}\text { Ascorbic acid; oxalic acid; dehydroascorbic acid; } \\
\text { pyruvic acid and glyoxalic acid }\end{array}$ & Chile & $\begin{array}{l}\text { Gusinde, 1936a,b; Montes } \\
\text { and Wilkomirsky, 1985; } \\
\text { Das, } 1990\end{array}$ \\
\hline $\begin{array}{l}\text { Phyllanthus amarus } \\
\text { Schum. \&Thonn. } \\
\text { (Phyllanthaceae) }\end{array}$ & $\begin{array}{l}\text { Fresh leaves are squeezed and juice is } \\
\text { utilized as eyes drops, } 2-3 \text { drops thrice } \\
\text { daily for } 7 \text { days. }\end{array}$ & Amariin & Tanzania & $\begin{array}{l}\text { Foo, 1993; Maregesi et al., } \\
2016\end{array}$ \\
\hline $\begin{array}{l}\text { Ribes punctatum Ruiz } \\
\text { \& Pav. } \\
\text { (Grossulariaceae) }\end{array}$ & Not described & $\begin{array}{l}\text { Cyanidin-3-glucoside; cyanidin-3-rutinoside; } \\
\text { delphinidin-3-rutinoside; delphinidin-3-glucoside; } \\
\text { 3-caffeoylquinic acid; (epi)-gallocatechin and } \\
\text { (epi)-catechin tetramers }\end{array}$ & Chile & $\begin{array}{l}\text { Gusinde, 1936a,b; } \\
\text { Jiménez-Aspee et al., } 2016\end{array}$ \\
\hline $\begin{array}{l}\text { Rumex usambarensis } \\
\text { (Dammer) } \\
\text { (Polygonaceae) }\end{array}$ & $\begin{array}{l}\text { Aerial parts are squeezed and the juice } \\
\text { is used as eye drops } 2 \text { times daily till } \\
\text { recovery. }\end{array}$ & Chrysophanol, physcion, and emodin & Tanzania & $\begin{array}{l}\text { Midiwo and Rukunga, } \\
\text { 1985; Maregesi et al., } 2016\end{array}$ \\
\hline $\begin{array}{l}\text { Stellaria media (L.) Vill. } \\
\text { (Caryophyllaceae) }\end{array}$ & Aerial parts are scrubbed in the eyes & $\begin{array}{l}\text { 2,4,5,7-tetramethyloctane; } \\
\text { 6-methylheptyl-3'-hydroxy-2'-methylpropanoate; } 2 \text {, } \\
\text { 2,4-trimethyloctan-3-one; apigenin 6-C- } \beta \text {-D- } \\
\text { galactopyranosyl-8-C- } \alpha \text {-L-arabinopyranoside; apigenin } \\
6 \text {-C- } \alpha \text {-L- arabinopyranosyl-8-C- } \alpha \text {-D-galactopyranoside }\end{array}$ & Chile & $\begin{array}{l}\text { Gusinde, 1936a,b; Hodisan } \\
\text { and Sancraian, 1989; } \\
\text { Kitanov, 1992; Pande et al., } \\
\text { 1995; Hu et al., 2006; } \\
\text { Vanhaecke et al., 2008; } \\
\text { Sharma and Arora, 2012; } \\
\text { Arora and Sharma, 2014 }\end{array}$ \\
\hline $\begin{array}{l}\text { Solanum lycopersicum } \\
\text { L. (Solanaceae) }\end{array}$ & $\begin{array}{l}\text { Fresh leaves are squeezed and the } \\
\text { juice is used as eye drops. }\end{array}$ & Adenosine & Tanzania & $\begin{array}{l}\text { Fuentes et al., 2012; } \\
\text { Maregesi et al., } 2016\end{array}$ \\
\hline
\end{tabular}


TABLE 6 | Continued

\begin{tabular}{|c|c|c|c|c|}
\hline Plant & $\begin{array}{c}\text { Formulations and mode of } \\
\text { administration }\end{array}$ & Major chemical constituents & Country & References \\
\hline $\begin{array}{l}\text { Solanum virginianum } L \text {. } \\
\text { (Solanaceae) }\end{array}$ & Seed is used & Arabinogalactan, glycosides & India & $\begin{array}{l}\text { Pattanayak et al., 2012; } \\
\text { Raja et al., } 2014\end{array}$ \\
\hline $\begin{array}{l}\text { Swietenia macrophylla } \\
\text { King (Meliaceae) }\end{array}$ & $\begin{array}{l}\text { One drop of fresh latex produced from } \\
\text { bark is used once daily }\end{array}$ & Swietemacrophyllanin; catechin and epicatechin & Tanzania & $\begin{array}{l}\text { Falah et al., 2008; } \\
\text { Maregesi et al., } 2016\end{array}$ \\
\hline $\begin{array}{l}\text { Thunbergia grandiflora } \\
\text { (Roxb. ex Rottl.) Roxb. } \\
\text { (Acanthaceae) }\end{array}$ & $\begin{array}{l}\text { Bubbles of } 1-2 \text { drops of the watery } \\
\text { latex from the stem are blown gently } \\
\text { into the affected eyes, } 3 \text { times a day for } \\
4-5 \text { days }\end{array}$ & Isounedoside and grandifloric acid & India & $\begin{array}{l}\text { Ismail et al., 1996; } \\
\text { Dipankar, } 2012\end{array}$ \\
\hline $\begin{array}{l}\text { Typha angustifolia L. } \\
\text { (Typhaceae) }\end{array}$ & New stems are applied on the eye & $\begin{array}{l}\text { Pentacosanoic acid; } \beta \text {-sitosterol; nonadecanol; } \\
\text { naringenin; daucosterol; uracil typhaneoside; nicotinic } \\
\text { acid; vanillic acid; succinic acid; thymine; stearic acid } \\
\text { propanetriol ester }\end{array}$ & Chile & $\begin{array}{l}\text { Gusinde, 1936a,b; Jia } \\
\text { et al., 1986; Liao et al., } \\
\text { 1990; Chen et al., 2008; } \\
\text { Varghese et al., 2009; } \\
\text { Shukla et al., } 2013\end{array}$ \\
\hline $\begin{array}{l}\text { Tridax procumbens (L.) } \\
\text { L. (Asteraceae) }\end{array}$ & $\begin{array}{l}\text { Leaf juice is dripped into the eyes to } \\
\text { treat cataract }\end{array}$ & Procumbentin & Nepal & Manandhar, 2002 \\
\hline $\begin{array}{l}\text { Vernonia amygdalina } \\
\text { Delile (Asteraceae) }\end{array}$ & $\begin{array}{l}\text { Fresh leaves are squeezed and the } \\
\text { juice is used as eyes drops, } 2-3 \text { drops } \\
\text { are used thrice daily for } 7 \text { days }\end{array}$ & Steroidal saponins; tannins; alkaloids; and flavonoids & Tanzania & $\begin{array}{l}\text { Omoregie and Pal, 2016; } \\
\text { Maregesi et al., } 2017\end{array}$ \\
\hline $\begin{array}{l}\text { Vitex negundo L. } \\
\text { (Lamiaceae) }\end{array}$ & NA & $\begin{array}{l}\text { Vitedoin A; vitedoamine A; vitexdoin A; flavonoids; } \\
\text { lignans; and terpenoids }\end{array}$ & India & $\begin{array}{l}\text { Tewar et al., 2013; Shu } \\
\text { et al., } 2016\end{array}$ \\
\hline
\end{tabular}

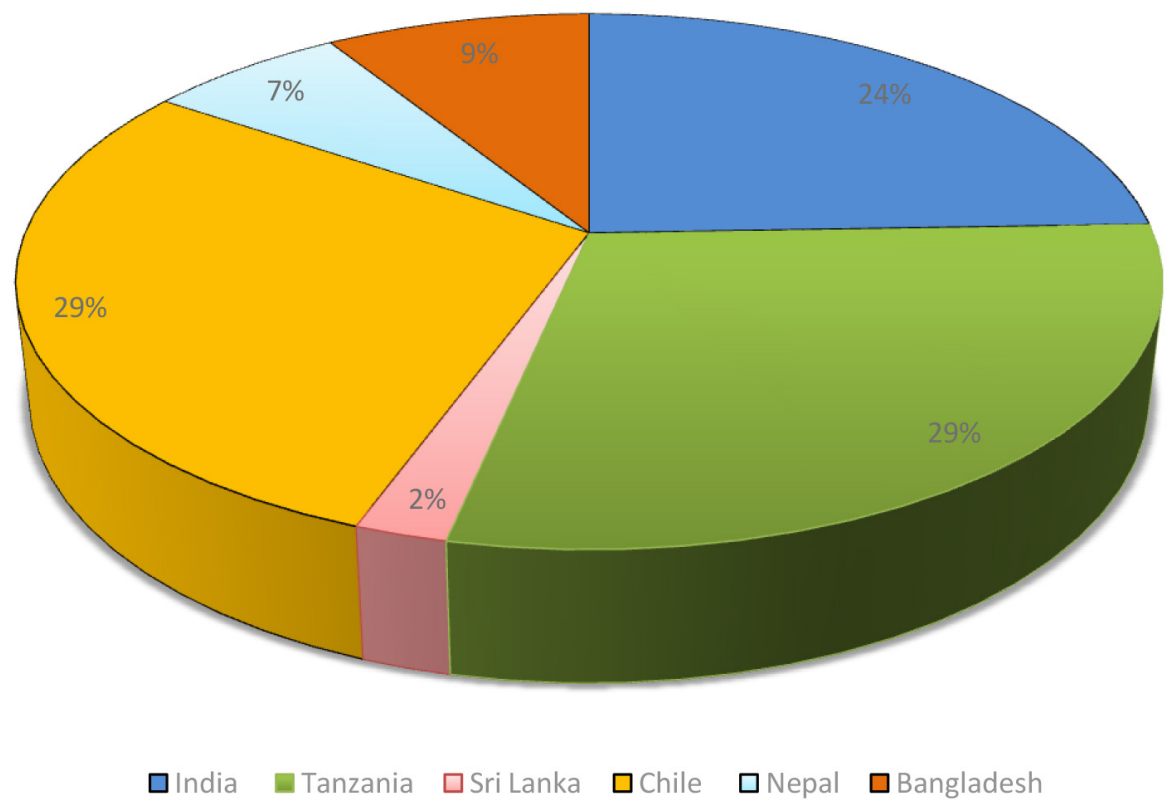

FIGURE 4 | Distribution of plants used in folklore medicine.

lens opacity/diabetes induced cataract models, AGE- BSA cross-linking inhibition assay, lens aldose reductase activity models, and hydrogen peroxide-induced cataract, and other miscellaneous models.

Diverse and sometimes complex phytochemicals present in numerous plants possess a broad spectrum of mechanisms for cataract treatment. One of the main mechanisms for the anticataract effect is the antioxidant effect (inhibitory effect on ROS formation). Several plants increase the activity of antioxidant enzymes as well. Some other important mechanisms involved are calpain inhibition, inhibition of lipid peroxidation, amelioration of calcium induced proteolysis, alteration in the protein profiles and the insolubilization of soluble proteins, attenuation in the inducible nitric oxide synthase expression, and AR inhibition.

For development of ocular drug delivery, various factors should be considered which affect the bioavailability of the ocular drugs. These factors include $\mathrm{pH}$, structural forms of the drug, osmolarity, viscosity, tonicity, and the salt form of the drug (Goodman, 1996). Increasing scientific evidence clearly reveals 
that natural products have the potential to combat cataract at different levels but at the same time critical evaluation for the safety and toxicity profiles are required. Despite of potential evidence for the significance of natural products against cataract, the possible clinical trials are still lacking.

\section{CONCLUSION}

Ethnopharmacological evaluation of the medicinal plants used for cataract treatment could be a beneficial approach for the development of potential natural product-based therapies against cataract. In this work we have analyzed over 120 papers and found that around 44 medicinal plants/natural products are used for cataract management in different traditional and folk medicine systems. Possible mechanisms of around 118 plants/natural products (including repetition in different models) are also studied. It is interesting that most of the ethnobotanical survey studies are reported from many developing countries like Bangladesh, Chile, India, Nepal, and Tanzania. The medicinal plants are not only utilized in the folk medicine but many of the plants are also mentioned for cataract management in the traditional systems of medicine like in Ayurveda, traditional Chinese medicine and in Korean tradition medicine. However, it is still of utmost importance to document more comprehensively the plants utilized in the traditional medicine and rigorous preclinical and clinical studies are required to validate the use of such plants.

It was also notable that some combinations of plants were also used such as KIOM-79 which is a mixture of ethanol extract $(80 \%)$ of parched Puerariae Radix, gingered Magnoliae Cortex, Glycyrrhizae Radix, and Euphorbiae Radix is used in Korean tradition medicine. Another such important combination formulation is 'Triphala' which is widely used

\section{REFERENCES}

Acharya, E., and Pokhrel, B. (2006). Ethno-medicinal plants used by bantar of bhaudaha, Morang, Nepal. Our Nat. 4, 96-103.

Agrawal, S. S., Naqvi, S., Gupta, S. K., and Srivastava, S. (2012). Prevention and management of diabetic retinopathy in STZ diabetic rats by Tinospora cordifolia and its molecular mechanisms. Food Chem. Toxicol. 50, 3126-3132. doi: 10. 1016/j.fct.2012.05.057

Ajani, E. O., Salako, A. A., Sharlie, P. D., Akinleye, W. A., Adeoye, A. O., Salau, B. A., et al. (2009). Chemopreventive and remediation effect of Hydrocotyl bonariensis Comm. Ex Lam (Apiaceae) leave extract in galactose-induced cataract. J. Ethnopharmacol. 123, 134-142. doi: 10.1016/j.jep.2009.02.006

Albert, D. M., and Edwards, D. D. (1996). The History of Ophthalmology. Cambridge: Blackwell Science.

Anitha, T. S., Annadurai, T., Thomas, P. A., and Geraldine, P. (2011). Prevention of selenite-induced cataractogenesis by an ethanolic extract of Cineraria maritima: an experimental evaluation of the traditional eye medication. Biol. Trace Elem. Res. 143, 425-436. doi: 10.1007/s12011-010-8876-x

Anitha, T. S., Muralidharan, A. R., Annadurai, T., Jesudasan, C. A. N., Thomas, P. A., and Geraldine, P. (2013). Putative free radical-scavenging activity of an extract of Cineraria maritima in preventing selenite-induced cataractogenesis in Wistar rat pups. Mol. Vis. 19, 2551-2560.

Arora, D., and Sharma, A. (2014). Isolation and characterization of the chemical constituents of Stellaria media Linn. Int. J. Pharm. Sci. Res. 5:3669.

Asha, R., Gayathri Devi, V., and Abraham, A. (2016). Lupeol, a pentacyclic triterpenoid isolated from Vernonia cinerea attenuate selenite induced cataract
Ayurvedic formulation in India containing fruits of Emblica officinalis Gaertn., Terminalia chebula Retz., and Terminalia belerica (Gaertn.) Roxb. However, many of the plants used in traditional medicines are not evaluated for their efficacy using rigorous scientific studies. Detailed mechanism-based in vitro and in vivo studies should be performed for the characterization of their possible pharmacological effects. On the other hand, evaluation of possible toxicity of these medicinal plants/natural products is also important as these medicines are directly applied in eyes and can have not just potential benefits but also harmful effects. Although there are numerous studies going on at preclinical level, clinical evidence for efficacy is still the need of the hour.

\section{AUTHOR CONTRIBUTIONS}

DT, OS, AM, DG, HD, JE, and AA drafted the initial manuscript. All authors improved, contributed, and agreed on the final version of the manuscript.

\section{ACKNOWLEDGMENTS}

AM acknowledges the support by a grant of the Romanian Ministry of Research and Innovation, CNCS - UEFISCDI, project number PN-III-P1-1.1-PD-2016-1900, within PNCDI III. AA acknowledges the support by the Polish KNOW (Leading National Research Center) Scientific Consortium Healthy Animal-Safe Food, decision of Ministry of Science and Higher Education No. 05-1/KNOW2/2015. The authors would like to express their gratitude to Ms. Izabela Zene for her excellent technical help in designing Figure $\mathbf{1}$.

formation in sprague dawley rat pups. Chem. Biol. Interact. 245, 20-29. doi: 10.1016/j.cbi.2015.12.002

Badwaik, H., Singh, M. K., Thakur, D., Giri, T. K., and Tripathi, D. K. (2011). The botany, chemistry, pharmacological and therapeutic application of Oxalis corniculata Linn-a review. Int. J. Phytomed. 3:1.

Bai, J., Zheng, Y., Dong, L., Cai, X., Wang, G., and Liu, P. (2015). Inhibition of p38 mitogen-activated protein kinase phosphorylation decreases $\mathrm{H}(2) \mathrm{O}(2)$-induced apoptosis in human lens epithelial cells. Graefes Arch. Clin. Exp. Ophthalmol. 253, 1933-1940. doi: 10.1007/s00417-015-3090-3093

Basnet, P., Kadota, S., Hase, K., and Namba, T. (1995). Five new C-methyl flavonoids, the potent aldose reductase inhibitors from Matteuccia orientalis TREV. Chem. Pharm. Bull. 43, 1558-1564. doi: 10.1248/cpb.43.1558

Bayala, B., Bassole, I. H. N., Gnoula, C., Nebie, R., Yonli, A., Morel, L., et al. (2014). Chemical composition, antioxidant, anti-inflammatory and anti-proliferative activities of essential oils of plants from Burkina Faso. PLoS One 9:e92122. doi: 10.1371/journal.pone.0092122

Bhadada, S. V., Bhadada, V. J., and Goyal, R. K. (2016a). Preventive effect of Tephrosia purpurea on selenite-induced experimental cataract. Curr. Eye Res. 41, 222-231. doi: 10.3109/02713683.2015.1011281

Bhadada, S. V., Vyas, V. K., and Goyal, R. K. (2016b). Protective effect of Tephrosia purpurea in diabetic cataract through aldose reductase inhibitory activity. Biomed. Pharmacother. 83, 221-228. doi: 10.1016/j.biopha.2016. 05.018

Bhati, H., and Manjusha, R. (2015). Clinical study on evaluation of anticataract effect of triphaladi ghana vati and elaneer kuzhambu anjana in timira (immature cataract). Ayu 36, 283-289. doi: 10.4103/0974-8520.182762 
Biju, P. G., Devi, V. G., Lija, Y., and Abraham, A. (2007). Protection against selenite cataract in rat lens by drevogenin D, a triterpenoid aglycone from Dregea volubilis. J. Med. Food 10, 308-315. doi: 10.1089/jmf.2006.054

Bisby, F. (1994). Phytochemical Dictionary of the Leguminosae. Boca Raton, FL: CRC Press.

Biswas, S., Shaw, R., Bala, S., and Mazumdar, A. (2016). Inventorization of some ayurvedic plants and their ethnomedicinal use in Kakrajhore forest area of West Bengal. J. Ethnopharmacol. 197, 231-241. doi: 10.1016/j.jep.2016. 08.014

Boti, J. B., Koukoua, G., N'Guessan, T. Y., and Casanova, J. (2007). Chemical variability of Conyza sumatrensis and Microglossa pyrifolia from Côte d'Ivoire. Flavour Fragr. J. 22, 27-31. doi: 10.1002/ffj.1743

Bottari, F., Marsili, A., Morelli, I., and Pacchiani, M. (1972). Aliphatic and triterpenoid hydrocarbons from ferns. Phytochemistry 11, 2519-2523.

Cao, S., Gao, M., Wang, N., Liu, N., Du, G., and Lu, J. (2015). Prevention of seleniteinduced cataratogenesis by Ginkgo biloba extract (Egb761) in wistar rats. Curr. Eye Res. 40, 1028-1033. doi: 10.3109/02713683.2014.980005

Cetinel, S., Semenchenko, V., Cho, J.-Y., Sharaf, M. G., Damji, K. F., Unsworth, L. D., et al. (2017). UV-B induced fibrillization of crystallin protein mixtures. PLoS One 12:e177991. doi: 10.1371/journal.pone.0177991

Chang, D., Zhang, X., Rong, S., Sha, Q., Liu, P., Han, T., et al. (2013). Serum antioxidative enzymes levels and oxidative stress products in age-related cataract patients. Oxid. Med. Cell. Longev. 2013:587826. doi: 10.1155/2013/ 587826

Chen, P., Yan, H., Zhang, L., and Ding, A. (2008). Study on the constituents of Typha angustifolia L. Strait Pharm. J. 12:33.

Chung, Y.-S., Choi, Y.-H., Lee, S.-J. A., Choi, S., Lee, J., Kim, H., et al. (2005). Water extract of Aralia elata prevents cataractogenesis in vitro and in vivo. J. Ethnopharmacol. 101, 49-54.

Cobos, M. I., Rodriguez, J. L., De Petre, A., Spahn, E., Casermeiro, J., Lopez, A. G., et al. (2002). Composition of the essential oil of Eryngium paniculatum cav. J. Essent. Oil Res. 14, 82-83.

Dailami, K. N., Azadbakht, M., Pharm, Z. R., and Lashgari, M. (2010). Prevention of selenite-induced cataractogenesis by Origanum vulgare extract. Pak. J. Biol. Sci. 13, 743-747. doi: 10.3923/pjbs.2010.743.747

Das, B., Kundu, J., Bachar, S. C., Uddin, M. A., and Kundu, J. K. (2007). Antitumor and antibacterial activity of ethylacetate extract of Ludwigia hyssopifolia Linn and its active principle piperine. Pak. J. Pharm. Sci. 20, 128-131.

Das, P. R., Islam, M. T., Mostafa, M. N., and Rahmatullah, M. (2013). Ethnomedicinal plants of the bauri tribal community of Moulvibazar district, Bangladesh. Anc. Sci. Life 32:144. doi: 10.4103/0257-7941.122997

Das, S. (1990). Biochemical Studies of Different Species of Oxalis in Relation to their Medicinal Values. Ph.D. thesis, Department of Botany, Utkal University, Bhubaneswar.

Delcourt, C., Cougnard-Grégoire, A., Boniol, M., Carrière, I., Doré, J.-F., Delyfer, M.-N., et al. (2014). Lifetime exposure to ambient ultraviolet radiation and the risk for cataract extraction and age-related macular degeneration: the alienor study. Investig. Opthalmol. Vis. Sci. 55:7619. doi: 10.1167/iovs.1414471

Demir, E., Taysi, S., Al, B., Demir, T., Okumus, S., Saygili, O., et al. (2016). The effects of Nigella sativa oil, thymoquinone, propolis, and caffeic acid phenethyl ester on radiation-induced cataract. Wien. Klin. Wochenschr. 128, 587-595. doi: 10.1007/s00508-015-0736-734

Dhal, Y., Sahu, R. K., and Deo, B. (2011). Ethno medicinal survey of Koraput District, Odisha: an update. J. Pharm. Res. 4, 4142-4145.

Dipankar, D. (2012). Traditional ethno-medicinal plants use by the Darlong tribes in Tripura, Northeast India. Int. J. Ayurvedic Herb. Med. 2, 954-966.

Doganay, S., Turkoz, Y., Evereklioglu, C., Er, H., Bozaran, M., and Ozerol, E. (2002). Use of caffeic acid phenethyl ester to prevent sodium-selenite-induced cataract in rat eyes. J. Cataract Refract. Surg. 28, 1457-1462.

Dongare, V., Kulkarni, C., Kondawar, M., Magdum, C., Haldavnekar, V., and Arvindekar, A. (2012). Inhibition of aldose reductase and anti-cataract action of trans-anethole isolated from Foeniculum vulgare Mill. fruits. Food Chem. 132, 385-390. doi: 10.1016/j.foodchem.2011.11.005

Dubey, S., Deep, P., and Singh, A. K. (2016). Phytochemical characterization and evaluation of anticataract potential of seabuckthorn leaf extract. Vet. Ophthalmol. 19, 144-148. doi: 10.1111/vop.12271
Dubey, S., Saha, S., Kaithwas, G., and Saraf, S. A. (2015a). Effect of standardized fruit extract of Luffa cylindrica on oxidative stress markers in hydrogen peroxide induced cataract. Indian J. Pharmacol. 47, 644-648. doi: 10.4103/0253-7613. 169586

Dubey, S., Saha, S., and Saraf, S. A. (2015b). In vitro anti-cataract evaluation of standardised Abies pindrow leaf extract using isolated goat lenses. Nat. Prod. Res. 29, 1145-1148. doi: 10.1080/14786419.2014.980250

Duke-Elder, S. (1962). System of Ophthalmology Vol VII: The Foundations of Ophthalmology-Heredity, Pathology, Diagnosis and Therapeutics. Maryland Heights, MO: Mosby.

Durukan, A. H., Evereklioglu, C., Hurmeric, V., Kerimoglu, H., Erdurman, C., Bayraktar, M. Z., et al. (2006). Ingestion of IH636 grape seed proanthocyanidin extract to prevent selenite-induced oxidative stress in experimental cataract. J. Cataract Refract. Surg. 32, 1041-1045. doi: 10.1016/j.jcrs.2006.02.041

Eilenberg, H., Pnini-Cohen, S., Rahamim, Y., Sionov, E., Segal, E., Carmeli, S., et al. (2010). Induced production of antifungal naphthoquinones in the pitchers of the carnivorous plant Nepenthes khasiana. J. Exp. Bot. 61, 911-922. doi: $10.1093 /$ jxb/erp359

El Okda, E. A., Mohamed, M. M., Shaheed, E. B., and Abdel-Moemin, A. R. (2016). Switching to instant black coffee modulates sodium selenite-induced cataract in rats. Ger. Med. Sci. 14:Doc05. doi: 10.3205/000232

Ertekin, M. V., Koçer, İ., Karslıoğlu, İ., Taysi, S., Gepdiremen, A., Sezen, O., et al. (2004). Effects of oral ginkgo biloba supplementation on cataract formation and oxidative stress occurring in lenses of rats exposed to total cranium radiotherapy. Jpn. J. Ophthalmol. 48, 499-502. doi: 10.1007/s10384-004-0101-z

Falah, S., Suzuki, T., and Katayama, T. (2008). Chemical constituents from Swietenia macrophylla bark and their antioxidant activity. Pak. J. Biol. Sci. 11, 2007-2012.

Fallah Huseini, H., Zaree Mahmodabady, A., Heshmat, R., and Raza, M. (2009). The effect of Silybum marianum (L.) Gaertn. Seed extract (Silymarin) on galactose induced cataract formation in rats. J. Med. Plants 1, 7-12.

Fan, X., Xiaoqin, L., Potts, B., Strauch, C. M., Nemet, I., and Monnier, V. M. (2011). Topical application of L-arginine blocks advanced glycation by ascorbic acid in the lens of hSVCT2 transgenic mice. Mol. Vis. 17, 2221-2227.

Fang, H., Hu, X., Wang, M., Wan, W., Yang, Q., Sun, X., et al. (2015). Anti-osmotic and antioxidant activities of gigantol from Dendrobium aurantiacum var. denneanum against cataractogenesis in galactosemic rats. J. Ethnopharmacol. 172, 238-246. doi: 10.1016/j.jep.2015.06.034

Fang, L., Guo, H., and Lou, H. (2007). Three new bibenzyl derivatives from the chinese liverwort Marchantia polymorpha L. Helv. Chim. Acta 90, 748-752.

Fang, L., Niu, C., and Lou, H. (2008). Studies on chemical constituents of Marchantia polymorpha L. Chin. Pharm. J. 43:18.

Ferlemi, A.-V., Makri, O. E., Mermigki, P. G., Lamari, F. N., and Georgakopoulos, C. D. (2016). Quercetin glycosides and chlorogenic acid in highbush blueberry leaf decoction prevent cataractogenesis in vivo and in vitro: investigation of the effect on calpains, antioxidant and metal chelating properties. Exp. Eye Res. 145, 258-268. doi: 10.1016/j.exer.2016.01.012

Foo, L. Y. (1993). Amariin, a di-dehydrohexahydroxydiphenoyl hydrolysable tannin from Phyllanthus amarus. Phytochemistry 33, 487-491.

Fuentes, E., Castro, R., Astudillo, L., Carrasco, G., Alarcon, M., Gutierrez, M., et al. (2012). Bioassay-guided isolation and HPLC determination of bioactive compound that relate to the antiplatelet activity (Adhesion, Secretion, and Aggregation) from Solanum lycopersicum. Evid. Based Compl. Alternat. Med. 2012:147031. doi: 10.1155/2012/147031

Gacche, R. N., and Dhole, N. A. (2011a). Aldose reductase inhibitory, anti-cataract and antioxidant potential of selected medicinal plants from the Marathwada region. India Nat. Prod. Res. 25, 760-763. doi: 10.1080/14786419.2010.536951

Gacche, R. N., and Dhole, N. A. (2011b). Profile of aldose reductase inhibition, anti-cataract and free radical scavenging activity of selected medicinal plants: an attempt to standardize the botanicals for amelioration of diabetes complications. Food Chem. Toxicol. 49, 1806-1813. doi: 10.1016/j.fct.2011. 04.032

Garaniya, N., and Bapodra, A. (2014). Ethno botanical and Phytophrmacological potential of Abrus precatorius L.: a review. Asian Pac. J. Trop. Biomed. 4, S27-S34. doi: 10.12980/APJTB.4.2014C1069

Gayathri Devi, V., Rooban, B. N., Sasikala, V., Sahasranamam, V., and Abraham, A. (2010). Isorhamnetin-3-glucoside alleviates oxidative stress and opacification in 
selenite cataract in vitro. Toxicol. Vitr. 24, 1662-1669. doi: 10.1016/j.tiv.2010. 05.021

Gbemisola, I. A., Faluyi, J. O., and Osoniyi, O. (2014). Evaluation of the effect of Spathodea campanulata flower bud exudate on cataractogenesis in rat lenses. Afr. J. Tradit. Compl. Altern. Med. 11, 83-91.

Geissberger, P., and Sequin, U. (1991). Constituents of Bidens pilosa L.: do the components found so far explain the use of this plant in traditional medicine? Acta Trop. 48, 251-261.

Gewali, M. B. (2011). Aspects of Traditional Medicine in Nepal. Oyama: University of Toyama.

Giblin, F. J. (2000). Glutathione: a vital lens antioxidant. J. Ocul. Pharmacol. Ther. 16, 121-135. doi: 10.1089/jop.2000.16.121

Golmakani, M., and Moayyedi, M. (2015). Comparison of heat and mass transfer of different microwave-assisted extraction methods of essential oil from Citrus limon (Lisbon variety) peel. Food Sci. Nutr. 3, 506-518. doi: 10.1002/ fsn 3.240

Goodman, L. S. (1996). Goodman and Gilman's the Pharmacological Basis of Therapeutics. New York, NY: McGraw-Hill.

Gupta, S. K., Halder, N., Srivastava, S., Trivedi, D., Joshi, S., and Varma, S. D. (2002). Green tea (Camellia sinensis) protects against selenite-induced oxidative stress in experimental cataractogenesis. Ophthalmic Res. 34, 258-263.

Gupta, S. K., Kalaiselvan, V., Srivastava, S., Agrawal, S. S., and Saxena, R. (2010a). Evaluation of anticataract potential of Triphala in selenite-induced cataract: in vitro and in vivo studies. J. Ayurveda Integr. Med. 1, 280-286. doi: 10.4103/ 0975-9476.74425

Gupta, S. K., Kalaiselvan, V., Srivastava, S., Saxena, R., and Agrawal, S. S. (2010b). Trigonella foenum-graecum (Fenugreek) protects against seleniteinduced oxidative stress in experimental cataractogenesis. Biol. Trace Elem. Res. 136, 258-268. doi: 10.1007/s12011-009-8540-8545

Gusinde, M. (1936a). Plantas medicinales que los indios Araucanos recomiendan. Anthropos 31, 850-873.

Gusinde, M. (1936b). Plantas medicinales que los indios Araucanos recomiendan. Anthropos 31, 555-571.

Guzman, A., and Guerrero, R. O. (2005). Inhibition of aldose reductase by herbs extracts and natural substances and their role in prevention of cataracts. Rev. Cuba. Plant Med. 10, 1-7.

Guzmán, Á, and Guerrero, R. O. (2005). Inhibition of aldose reductase by herbs extracts and natural substances and their role in prevention of cataracts. Rev. Cuba. Plantas Med. 10, 3-4.

Halder, N., Joshi, S., and Gupta, S. K. (2003). Lens aldose reductase inhibiting potential of some indigenous plants. J. Ethnopharmacol. 86, 113-116. doi: 10. 1016/S0378-8741(03)00052-57

Halder, N., Joshi, S., Nag, T. C., Tandon, R., and Gupta, S. K. (2009). Ocimum sanctum extracts attenuate hydrogen peroxide induced cytotoxic ultrastructural changes in human lens epithelial cells. Phytother. Res. 23, 1734-1737. doi: $10.1002 /$ ptr. 2831

Harikumar, K. B., Nimita, C. V., Preethi, K. C., Kuttan, R., Shankaranarayana, M. L., and Deshpande, J. (2008). Toxicity profile of lutein and lutein ester isolated from marigold flowers (Tagetes erecta). Int. J. Toxicol. 27, 1-9. doi: $10.1080 / 10915810701876265$

Hashim, Z., and Zarina, S. (2012). Osmotic stress induced oxidative damage: possible mechanism of cataract formation in diabetes. J. Diabetes Complications 26, 275-279. doi: 10.1016/j.jdiacomp.2012.04.005

Hedberg, I., Hedberg, O., Madati, P. J., Mshigeni, K. E., Mshiu, E. N., and Samuelsson, G. (1983). Inventory of plants used in traditional medicine in Tanzania. Part III. Plants of the families Papilionaceae-Vitaceae. J. Ethnopharmacol. 9, 237-260.

Hejtmancik, J. F., and Kantorow, M. (2004). Molecular genetics of age-related cataract. Exp. Eye Res. 79, 3-9. doi: 10.1016/j.exer.2004.03.014

Hodisan, V., and Sancraian, A. (1989). Triterpenoid saponins from Stellaria media (L.) Cyr. Farmacia 37:105.

Hu, Y.-M., Ye, W.-C., Li, Q., Tian, H.-Y., Wang, H., and Du, H.-Y. (2006). C-glycosylflavones from Stellaria media. Zhongguo Tianran Yaowu 4, 420-424.

Huang, R., Shi, F., Lei, T., Song, Y., Hughes, C. L., and Liu, G. (2007). Effect of the isoflavone genistein against galactose-induced cataracts in rats. Exp. Biol. Med. 232, 118-125.

Isai, M., Elanchezhian, R., Sakthivel, M., Chinnakkaruppan, A., Rajamohan, M., Jesudasan, C. N., et al. (2009). Anticataractogenic effect of an extract of the oyster mushroom, Pleurotus ostreatus, in an experimental animal model. Curr. Eye Res. 34, 264-273. doi: 10.1080/02713680902774069

Islam, M. S., Rahman, M. M., Rahman, M. A., Qayum, M. A., and Alam, M. F. (2010). In vitro evaluation of Croton bonplandianum Baill. as potential antitumor properties using Agrobacterium tumefaciens. J. Agric. Technol. 6, 79-86.

Ismail, L. D., el-Azizi, M. M., Khalifa, T. I., and Stermitz, F. R. (1996). Iridoid glycosides from Thunbergia grandiflora. Phytochemistry 42, 1223-1225.

Jaiswal, N., Bhatia, V., Srivastava, S. P., Srivastava, A. K., and Tamrakar, A. K. (2012). Antidiabetic effect of Eclipta alba associated with the inhibition of alpha-glucosidase and aldose reductase. Nat. Prod. Res. 26, 2363-2367. doi: 10.1080/14786419.2012.662648

Jaiswal, S. K., Dubey, M. K., Das, S., and Rao, C. V. (2014). Gastroprotective effect of the iridoid fraction from Barleria prionitis leaves on experimentally-induced gastric ulceration. Chin. J. Nat. Med. 12, 738-744. doi: 10.1016/S1875-5364(14) 60113-8

Jang, D. S., Lee, Y. M., Jeong, I. H., and Kim, J. S. (2010a). Constituents of the flowers of Platycodon grandiflorum with inhibitory activity on advanced glycation end products and rat lens aldose reductase in vitro. Arch. Pharm. Res. 33, 875-880. doi: 10.1007/s12272-010-0610-x

Jang, D. S., Yoo, N. H., Kim, N. H., Lee, Y. M., Kim, C.-S., Kim, J., et al. (2010b). 3,5-Di-O-caffeoyl-epi-quinic acid from the leaves and stems of Erigeron annuus inhibits protein glycation, aldose reductase, and cataractogenesis. Biol. Pharm. Bull. 33, 329-333.

Jang, D. S., Yoo, N. H., Lee, Y. M., Yoo, J. L., Kim, Y. S., and Kim, J. S. (2008). Constituents of the flowers of Erigeron annuus with inhibitory activity on the formation of advanced glycation end products (AGEs) and aldose reductase. Arch. Pharm. Res. 31:900. doi: 10.1007/s12272-001-1244-z

Javadzadeh, A., Ghorbanihaghjo, A., Arami, S., Rashtchizadeh, N., Mesgari, M. Rafeey, M., et al. (2009a). Prevention of selenite-induced cataractogenesis in wistar albino rats by aqueous extract of garlic. J. Ocul. Pharmacol. Ther. 25, 395-400. doi: 10.1089/jop.2009.0038

Javadzadeh, A., Ghorbanihaghjo, A., Bonyadi, S., Rashidi, M., Mesgari, M., Rashtchizadeh, N., et al. (2009b). Preventive effect of onion juice on seleniteinduced experimental cataract. Indian J. Ophthalmol. 57:185. doi: 10.4103/ 0301-4738.49391

Jia, S.-S., Liu, Y.-L., Ma, C.-M., Yang, S.-L., Zhou, H.-M., Zhao, D.-C., et al. (1986). Studies on the constituents of the flavonoids from the pollen of Typha angustfolia L.(Puhuang). Yao Xue Xue Bao 21, 441-446.

Jia, Z., Song, Z., Zhao, Y., Wang, X., and Liu, P. (2011). Grape seed proanthocyanidin extract protects human lens epithelial cells from oxidative stress via reducing NF-small ka, CyrillicB and MAPK protein expression. Mol. Vis. 17, 210-217.

Jiménez-Aspee, F., Theoduloz, C., Vieira, M. N., Rodríguez-Werner, M. A., Schmalfuss, E., Winterhalter, P., et al. (2016). Phenolics from the Patagonian currants Ribes spp: isolation, characterization and cytoprotective effect in human AGS cells. J. Funct. Foods 26, 11-26.

Kadota, S., Basnet, P., Hase, K., and Namba, T. (1994). Matteuorienate A and B, two new and potent aldose reductase inhibitors from Matteuccia orientalis (Hook.) Trev. Chem. Pharm. Bull. 42, 1712-1714.

Kang, K. D., Kang, S. M., and Yim, H. B. (2008). Herbal medication aggravates cataract formation: a case report. J. Korean Med. Sci. 23, 537-539. doi: 10.3346/ jkms.2008.23.3.537

Kapkoti, B., Lodhiyal, N., and Lodhiyal, L. S. (2011). Ethno-medicinal plants and their uses by van panchayat people in nainital of kumaun region, Uttarakhand. Biolife 2, 526-532.

Khairallah, M., Kahloun, R., Bourne, R., Limburg, H., Flaxman, S. R., Jonas, J. B., et al. (2015). Number of people blind or visually impaired by cataract worldwide and in world regions, 1990 to 2010. Invest. Ophthalmol. Vis. Sci. 56, 6762-6769. doi: 10.1167/iovs.15-17201

Khalid, H., Abdalla, W. E., Abdelgadir, H., Opatz, T., and Efferth, T. (2012). Gems from traditional north-African medicine: medicinal and aromatic plants from Sudan. Nat. Prod. Bioprospect. 2, 92-103. doi: 10.1007/s13659-0120015-2

Kim, C.-S., Kim, J., Lee, Y. M., Sohn, E., Jo, K., and Kim, J. S. (2011a). Inhibitory effects of chlorogenic acid on aldose reductase activity in vitro and cataractogenesis in galactose-fed rats. Arch. Pharm. Res. 34, 847-852. doi: 10. 1007/s12272-011-0519-z 
Kim, J., Kim, C.-S., Sohn, E., Kim, H., Jeong, I.-H., and Kim, J. S. (2011b). KIOM-79 prevents lens epithelial cell apoptosis and lens opacification in zucker diabetic fatty rats. Evid. Based Compl. Alternat. Med. 2011:717921. doi: 10.1155/2011/ 717921

Kim, J., Kim, C.-S., Sohn, E., Lee, Y. M., and Kim, J. S. (2011c). KIOM-79 inhibits aldose reductase activity and cataractogenesis in Zucker diabetic fatty rats. J. Pharm. Pharmacol. 63, 1301-1308. doi: 10.1111/j.2042-7158.2011.01341.x

Kim, C.-S., Kim, J.-H., Jeong, I.-H., Kim, Y.-S., Lee, J., Jang, D.-S., et al. (2009). Slow development of diabetic cataract in streptozotocin-induced diabetic rats via inhibition of aldose reductase activity and sorbitol accumulation by use of Aster koraiensis extract. Korean J. Pharmacogn. 40, 339-344.

Kim, N. H., Kim, Y. S., Lee, Y. M., Jang, D. S., and Kim, J. S. (2010). Inhibition of aldose reductase and xylose-induced lens opacity by puerariafuran from the roots of Pueraria lobata. Biol. Pharm. Bull. 33, 1605-1609.

Kitanov, G. M. (1992). Phenolic acids and flavanoids from Stellaria media (L.) Vill.(caryophyllaceae). Pharmazie 47, 470-471.

Konozy, E. H. E., Mulay, R., Faca, V., Ward, R. J., Greene, L. J., RoqueBarriera, M. C., et al. (2002). Purification, some properties of a D-galactosebinding leaf lectin from Erythrina indica and further characterization of seed lectin. Biochimie 84, 1035-1043. doi: 10.1016/S0300-9084(02)0 0003-2

Kubo, M., Matsuda, H., Tokuoka, K., Kobayashi, Y., and Tanaka, T. (1994). Studies of anti-cataract drugs from natural sources. I. Effects of a methanolic extract and the alkaloidal components from Corydalis tuber on in vitro aldose reductase activity. Biol. Pharm. Bull. 17, 458-459.

Kulkarni, R. R., Virkar, A. D., and D'mello, P. (2008). Antioxidant and antiinflammatory activity of Vitex negundo. Indian J. Pharm. Sci. 70, 838-840. doi: 10.4103/0250-474X.49140

Kumar, D., and Singh, R. (2011). Anti cataract activity of Acorus calamus Linn. against hydrogen peroxide induced cataractogenesis in Goat eyes. Int. J. Pharm. Sci. Rev. Res. 11, 112-115.

Kumar, R., Patel, D. K., Laloo, D., Sairam, K., and Hemalatha, S. (2011). Inhibitory effect of two Indian medicinal plants on aldose reductase of rat lens in vitro. Asian Pac. J. Trop. Med. 4, 694-697. doi: 10.1016/S1995-7645(11) 60176-4

Kumar, S., Malhotra, R., and Kumar, D. (2010). Euphorbia hirta: its chemistry, traditional and medicinal uses, and pharmacological activities. Pharmacogn. Rev. 4, 58-61. doi: 10.4103/0973-7847.65327

Lee, J., Jang, D. S., Kim, N. H., Lee, Y. M., Kim, J., and Kim, J. S. (2011). Galloyl glucoses from the seeds of Cornus officinalis with inhibitory activity against protein glycation, aldose reductase, and cataractogenesis ex vivo. Biol. Pharm. Bull. 34, 443-446.

Lee, J., Kim, N. H., Nam, J. W., Lee, Y. M., Jang, D. S., Kim, Y. S., et al. (2010). Scopoletin from the flower buds of Magnolia fargesii inhibits protein glycation, aldose reductase, and cataractogenesis ex vivo. Arch. Pharm. Res. 33, 1317-1323. doi: 10.1007/s12272-010-0904-z

Lee, Y. S., Ju, H. K., Kim, Y. J., Lim, T.-G., Uddin, M. R., Kim, Y. B., et al. (2013). Enhancement of anti-inflammatory activity of Aloe vera adventitious root extracts through the alteration of primary and secondary metabolites via salicylic acid elicitation. PLoS One 8:e82479. doi: 10.1371/journal.pone.008 2479

Li, X., Liu, W., Huang, X., Xiong, J., and Wei, X. (2017). Interaction of AR and iNOS in lens epithelial cell: a new pathogenesis and potential therapeutic targets of diabetic cataract. Arch. Biochem. Biophys. 615, 44-52. doi: 10.1016/j.abb.2017. 01.007

Liao, J.-H., Huang, Y.-S., Lin, Y.-C., Huang, F.-Y., Wu, S.-H., and Wu, T.-H. (2016). Anticataractogenesis mechanisms of curcumin and a comparison of its degradation products: an in vitro study. J. Agric. Food Chem. 64, 2080-2086. doi: $10.1021 /$ acs.jafc. 6 b00430

Liao, M., Liu, Y., and Xiao, P. (1990). Studies on the constituents of the flavonoids from the leaves of Typha angustifolia L. Acta Bot. Sin. 32, 137-140.

Lija, Y., Biju, P. G., Reeni, A., Cibin, T. R., Sahasranamam, V., and Abraham, A. (2006). Modulation of selenite cataract by the flavonoid fraction of Emilia sonchifolia in experimental animal models. Phytother. Res. 20, 1091-1095. doi: $10.1002 /$ ptr.2005

Linky, S. A., Tonny, F. T., Zaman, N., Rahman, A., Mim, S. J., Islam, E., et al. (2015). Phytotherapy in Kishoreganj district, Bangladesh-Part I. World J. Pharm. Pharm. Sci. 4, 274-283.
Lu, Q., Yang, T., Zhang, M., Du, L., Liu, L., Zhang, N., et al. (2014). Preventative effects of Ginkgo biloba extract (EGb761) on high glucose-cultured opacity of rat lens. Phytother. Res. 28, 767-773. doi: 10.1002/ptr.5060

Mahajan, K. N., Singhai, A. K., and Vadnere, G. P. (2011). Investigation on anticataract activity of Triphala ghrita. J. Chem. 8, 1438-1443.

Mai, T. T., Yamaguchi, K., Yamanaka, M., Lam, N. T., Otsuka, Y., and Chuyen, N. V. (2010). Protective and anticataract effects of the aqueous extract of Cleistocalyx operculatus flower buds on beta-cells of streptozotocin-diabetic rats. J. Agric. Food Chem. 58, 4162-4168. doi: 10.1021/jf904304w

Makri, O. E., Ferlemi, A.-V., Lamari, F. N., and Georgakopoulos, C. D. (2013). Saffron administration prevents selenite-induced cataractogenesis. Mol. Vis. 19, 1188-1197.

Manandhar, N. P. (2002). Plants and people of Nepal timber press. Oregon 192, 526-527.

Mani Satyam, S., Kurady Bairy, L., Pirasanthan, R., and Lalit Vaishnav, R. (2014). Grape seed extract and zinc containing nutritional food supplement prevents onset and progression of age-related cataract in wistar rats. J. Nutr. Health Aging 18, 524-530. doi: 10.1007/s12603-014-0020-28

Manikandan, R., Thiagarajan, R., Beulaja, S., Chindhu, S., Mariammal, K., Sudhandiran, G., et al. (2009). Anti-cataractogenic effect of curcumin and aminoguanidine against selenium-induced oxidative stress in the eye lens of wistar rat pups: an in vitro study using isolated lens. Chem. Biol. Interact. 181, 202-209. doi: 10.1016/j.cbi.2009.05.011

Maregesi, S., Kauke, B., Kagashe, G., and Kaali, R. (2016). Traditional eye medicines in tanzania: products, health risk awareness and safety evaluation. Herb. Med. Open Access 2:1.

Maregesi, S. M., Messo, C. W., and Mathias, J. (2017). Ethnomedical survey and safety evaluation of traditional eye medicines used in Misungwi district, Tanzania. J. Intercult. Ethnopharmacol. 6, 75-83. doi: 10.5455/jice. 20161116071244

Matsuda, H., Cai, H., Kubo, M., TosA, H., and Iinuma, M. (1995). Study on anticataract drugs from natural sources. II. Effects of buddlejae flos on in vitro aldose reductase activity. Biol. Pharm. Bull. 18, 463-466.

Meng, D.-H., Wu, J., Wang, L.-Y., and Zhao, W.-M. (2010). Two new glycosides from Breynia vitis-idaea. J. Asian Nat. Prod. Res. 12, 535-541. doi: 10.1080/ 10286021003745452

Midiwo, J. O., and Rukunga, G. M. (1985). Distribution of anthraquinone pigments in Rumex species of Kenya. Phytochemistry 24, 1390-1391.

Miyatake, K., Kensho, G., Fujimoto, T., Noguchi, E., Shinohara, M., Takenaka, S., et al. (1994). Effect of conduritol A, a polyol from gymnema sylvestre, on the development of diabetic cataracts in streptozotocin-treated rats and on aldose reductase. Biosci. Biotechnol. Biochem. 58, 756-757.

Moeller, S. M., Jacques, P. F., and Blumberg, J. B. (2000). The potential role of dietary xanthophylls in cataract and age-related macular degeneration. J. Am. Coll. Nutr. 19, 522S-527S.

Montes, M., and Wilkomirsky, T. (1985). Medicina Popular Chilena. Chile: Universidad de Concepción, Concepción.

Morimitsu, Y., Kubota, K., Tashiro, T., Hashizume, E., Kamiya, T., and Osawa, T. (2002). Inhibitory effect of anthocyanins and colored rice on diabetic cataract formation in the rat lenses. Int. Congr. Ser. 1245, 503-508.

Morimitsu, Y., Yoshida, K., Esaki, S., and Hirota, A. (1995). Protein glycation inhibitors from thyme (Thymus vulgaris). Biosci. Biotechnol. Biochem. 59, 2018 2021.

Muthenna, P., Akileshwari, C., Saraswat, M., and Reddy, G. B. (2012). Inhibition of advanced glycation end-product formation on eye lens protein by rutin. $\mathrm{Br}$. J. Nutr. 107, 941-949. doi: 10.1017/S0007114511004077

Muthenna, P., Raghu, G., Akileshwari, C., Sinha, S. N., Suryanarayana, P., and Reddy, G. B. (2013). Inhibition of protein glycation by procyanidin-B2 enriched fraction of cinnamon: delay of diabetic cataract in rats. IUBMB Life 65, 941-950. doi: 10.1002/iub.1214

Nair, N. K., Patel, K., and Gandhi, T. (2010). Effect of aqueous extract of Embelica offcinalis on selenite induced cataract in rats. Iran. J. Pharm. Res. 9, 147-152.

Nakajima, T., Shearer, T. R., and Azuma, M. (2014). Loss of calpastatin leads to activation of calpain in human lens epithelial cells. Invest. Ophthalmol. Vis. Sci. 55, 5278-5283. doi: 10.1167/iovs.14-14778

Obrosova, I. G., Chung, S. S. M., and Kador, P. F. (2010). Diabetic cataracts: mechanisms and management. Diabetes Metab. Res. Rev. 26, 172-180. doi: 10.1002/dmrr.1075 
Ogunlowo, O. P., Arimah, B. D., and Adebayo, M. A. (2013). Phytochemical analysis and comparison of in-vitro antimicrobial activities of the leaf, stem bark and root bark of Ficus benghalensis. IOSR J. Pharm. 3, 33-38.

Ohia, S. E., Opere, C. A., and Leday, A. M. (2005). Pharmacological consequences of oxidative stress in ocular tissues. Mutat. Res. 579, 22-36. doi: 10.1016/j. mrfmmm.2005.03.025

Okano, Y., Asada, M., Fujimoto, A., Ohtake, A., Murayama, K., Hsiao, K.-J., et al. (2001). A genetic factor for age-related cataract: identification and characterization of a novel galactokinase variant, "Osaka," in asians. Am. J. Hum. Genet. 68, 1036-1042.

Oliveira, P. E., Cunha, A. G., Reyes, G., Gacitúa, W., and Petit-Breuilh, X. (2016). Chusquea quila, a natural resource from Chile: its chemical, physical, and nanomechanical properties. BioResources 11, 10057-10069.

Omoregie, E. S., and Pal, A. (2016). Antiplasmodial, antioxidant and immunomodulatory activities of ethanol extract of Vernonia amygdalina del. Leaf in Swiss mice. Avicenna J. Phytomed. 6, 236-247.

Onkaramurthy, M., Veerapur, V. P., Thippeswamy, B. S., Reddy, T. N. M., Rayappa, H., and Badami, S. (2013). Anti-diabetic and anti-cataract effects of Chromolaena odorata Linn., in streptozotocin-induced diabetic rats. J. Ethnopharmacol. 145, 363-372. doi: 10.1016/j.jep.2012.11.023

Osakabe, N., Yamagishi, M., Natsume, M., Yasuda, A., and Osawa, T. (2004). Ingestion of proanthocyanidins derived from cacao inhibits diabetes-induced cataract formation in rats. Exp. Biol. Med. 229, 33-39.

Panaskar, S. N., Joglekar, M. M., Taklikar, S. S., Haldavnekar, V. S., and Arvindekar, A. U. (2013). Aegle marmelos correa leaf extract prevents secondary complications in streptozotocin-induced diabetic rats and demonstration of limonene as a potent antiglycating agent. J. Pharm. Pharmacol. 65, 884-894. doi: $10.1111 /$ jphp.12044

Pande, A., Shukla, Y. N., and Tripathi, A. K. (1995). Lipid constituents from Stellaria media. Phytochemistry 39, 709-711.

Parinitha, M., Harish, G. U., Vivek, N. C., Mahesh, T., and Shivanna, M. B. (2004). Ethno-botanical wealth of Bhadra wild life sanctuary in Karnataka. Indian J. Traditi. Knowl. 3, 37-50.

Patel, D., Kumar, R., Kumar, M., Sairam, K., and Hemalatha, S. (2012). Evaluation of in vitro aldose reductase inhibitory potential of different fraction of Hybanthus enneaspermus Linn F. Muell. Asian Pac. J. Trop. Biomed. 2, 134-139. doi: 10.1016/S2221-1691(11)60207-4

Patel, M. B., and Mishra, S. M. (2009). Aldose reductase inhibitory activity of a C-glycosidic flavonoid derived from Enicostemma hyssopifolium. J. Compl. Integr. Med. 6:5.

Patil, K. K., Meshram, R. J., Dhole, N. A., and Gacche, R. N. (2016). Role of dietary flavonoids in amelioration of sugar induced cataractogenesis. Arch. Biochem. Biophys. 593, 1-11. doi: 10.1016/j.abb.2016.01.015

Pattanayak, S., Dutta, M. K., Debnath, P. K., Bandyopadhyay, S. K., Saha, B., and Maity, D. (2012). A study on ethno-medicinal use of some commonly available plants for wound healing and related activities in three southern districts of West Bengal, India. Explor. Anim. Med. Res. 2, 97-110.

Pendota, S. C., Grierson, D. S., and Afolayan, A. J. (2008). An ethnobotanical study of plants used for the treatment of eye infections in the Eastern Cape Province, South Africa. Pak. J. Biol. Sci. 11, 2051-2053.

Phillipson, J. D. (1995). A matter of some sensitivity. Phytochemistry 38, 13191343.

Pohl, S., Zobel, J., and Moffat, A. (2010). "Extended boolean retrieval for systematic biomedical reviews," in Proceedings of the Thirty-Third Australasian Conferenc on Computer Science - Volume 102 ACSC'10, (Darlinghurst, NSW: Australian Computer Society, Inc), 117-126.

Pollreisz, A., and Schmidt-Erfurth, U. (2010). Diabetic cataract-pathogenesis, epidemiology and treatment. J. Ophthalmol. 2010:608751. doi: 10.1155/2010/ 608751

Prajapati, R., Kalariya, M., Umbarkar, R., Parmar, S., and Sheth, N. (2011). Colocasia esculenta: a potent indigenous plant. Int. J. Nutr. Pharmacol. Neurol. Dis. 1:90.

Prokofyeva, E., Wegener, A., and Zrenner, E. (2013). Cataract prevalence and prevention in Europe: a literature review. Acta Ophthalmol. 91, 395-405. doi: 10.1111/j.1755-3768.2012.02444.x

Puppala, M., Ponder, J., Suryanarayana, P., Reddy, G. B., Petrash, J. M., and LaBarbera, D. V. (2012). The isolation and characterization of beta-glucogallin as a novel aldose reductase inhibitor from Emblica officinalis. PLoS One 7:e31399. doi: 10.1371/journal.pone.0031399

Radulovic, N., Dekic, M., Stojanovic-Radic, Z., and Palic, R. (2011). Chemical composition and antimicrobial activity of the essential oils of Geranium columbinum L. and G. lucidum L.(Geraniaceae). Turk. J. Chem. 35, 499-512.

Ragasa, C. Y., Lorena, G. S., Mandia, E. H., Raga, D. D., and Shen, C.-C. (2013). Chemical constituents of Abrus precatorius. Am. J. Essent. Oils Nat. Prod. 1, $7-10$.

Raja, W., Nosalova, G., Ghosh, K., Sivova, V., Nosal, S., and Ray, B. (2014). In vivo antitussive activity of a pectic arabinogalactan isolated from Solanum virginianum L. in guinea pigs. J. Ethnopharmacol. 156, 41-46. doi: 10.1016/j. jep.2014.08.012

Rajalakshmi, M., Eliza, J., Priya, C. E., Nirmala, A., and Daisy, P. (2009). Antidiabetic properties of Tinospora cordifolia stem extracts on streptozotocininduced diabetic rats. Afr. J. Pharm. Pharmacol. 3, 171-180.

Rajamanoharan, P. R. (2014). An ethno botanical survey of medicinal plants in Sillalai, Jaffna, Northern Province, Sri Lanka. Int. J. Herb. Med. 1, 22-30.

Rajkumar, S., Vasavada, A. R., Praveen, M. R., Ananthan, R., Reddy, G. B., Tripathi, H., et al. (2013). Exploration of molecular factors impairing superoxide dismutase isoforms activity in human senile cataractous lenses. Invest. Ophthalmol. Vis. Sci. 54, 6224-6233. doi: 10.1167/iovs.13-11935

Raju, T. N., Kanth, V. R., and Lavanya, K. (2008). Effect of methanolic extract of Allium sativum (AS) in delaying cataract in STZ-induced diabetic rats. J. Ocul. Biol. Dis. Infor. 1, 46-54. doi: 10.1007/s12177-008-9003-5

Ramana, K. V. (2011). ALDOSE REDUCTASE: new insights for an old enzyme. Biomol. Concepts 2, 103-114. doi: 10.1515/BMC.2011.002

Rathi, S. S., Grover, J. K., Vikrant, V., and Biswas, N. R. (2002). Prevention of experimental diabetic cataract by indian ayurvedic plant extracts. Phytother. Res. 16, 774-777. doi: 10.1002/ptr.1064

Reddy, V. S., Kumar, C. U., and Reddy, G. B. (2014). Effect of chronic hyperglycemia on crystallin levels in rat lens. Biochem. Biophys. Res. Commun. 446, 602-607. doi: 10.1016/j.bbrc.2014.03.012

Rooban, B. N., Lija, Y., Biju, P. G., Sasikala, V., Sahasranamam, V., and Abraham, A. (2009). Vitex negundo attenuates calpain activation and cataractogenesis in selenite models. Exp. Eye Res. 88, 575-582. doi: 10.1016/j.exer.2008.11.020

Rooban, B. N., Sasikala, V., Devi, V. G., Sahasranamam, V., and Abraham, A. (2012). Prevention of selenite induced oxidative stress and cataractogenesis by luteolin isolated from Vitex negundo. Chem. Biol. Interact. 196, 30-38. doi: 10.1016/j.cbi.2012.01.005

Rooban, B. N., Sasikala, V., Sahasranamam, V., and Abraham, A. (2010). Vitex negundo modulates selenite-induced opacification and cataractogensis in rat pups. Biol. Trace Elem. Res. 138, 282-292. doi: 10.1007/s12011-010-8633-8631

Rooban, B. N., Sasikala, V., Sahasranamam, V., and Abraham, A. (2011). Analysis on the alterations of lens proteins by Vitex negundo in selenite cataract models. Mol. Vis. 17, 1239-1248.

Rothe, S. P., and Maheshwari, A. A. (2016). Traditional herbal medicine for ophthalmic diseases used by tribals in melghat region. Sciences 6, 75-78.

Sachdev, M. (2017). Cataract surgery: the journey thus far. Indian J. Ophthalmol. 65, 1273-1274. doi: 10.4103/ijo.IJO-1098-17

Sai Varsha, M. K. N., Raman, T., and Manikandan, R. (2014). Inhibition of diabetic-cataract by vitamin $\mathrm{K} 1$ involves modulation of hyperglycemia-induced alterations to lens calcium homeostasis. Exp. Eye Res. 128, 73-82. doi: 10.1016/ j.exer.2014.09.007

Sakthivel, M., Elanchezhian, R., Ramesh, E., Isai, M., Jesudasan, C. N., Thomas, P. A., et al. (2008). Prevention of selenite-induced cataractogenesis in wistar rats by the polyphenol, ellagic acid. Exp. Eye Res. 86, 251-259.

Sandhu, P. S., Singh, B., Gupta, V., Bansal, P., and Kumar, D. (2011). Potential herbs used in ocular diseases. J. Pharm. Sci. Res. 3, 1127-1140.

Sankeshi, V., Kumar, P. A., Naik, R. R., Sridhar, G., Kumar, M. P., Gopal, V. V. H., et al. (2013). Inhibition of aldose reductase by Aegle marmelos and its protective role in diabetic cataract. J. Ethnopharmacol. 149, 215-221. doi: 10.1016/j.jep. 2013.06.025

Saraswat, M., Suryanarayana, P., Reddy, P. Y., Patil, M. A., Balakrishna, N., and Reddy, G. B. (2010). Antiglycating potential of Zingiber officinalis and delay of diabetic cataract in rats. Mol. Vis. 16, 1525-1537. 
Sasikala, V., Rooban, B. N., Priya, S. G. S., Sahasranamam, V., and Abraham, A. (2010). Moringa oleifera prevents selenite-induced cataractogenesis in rat pups. J. Ocul. Pharmacol. Ther. 26, 441-447. doi: 10.1089/jop.2010.0049

Sasikala, V., Rooban, B. N., Sahasranamam, V., and Abraham, A. (2013). Rutin ameliorates free radical mediated cataract by enhancing the chaperone activity of alpha-crystallin. Graefes Arch. Clin. Exp. Ophthalmol. 251, 1747-1755. doi: 10.1007/s00417-013-2281-z

Sharma, A., and Arora, D. (2012). Phytochemical and pharmacological potential of genus Stellaria: a review. J Pharm. Res. 5, 3591-3596.

Shiels, A., and Hejtmancik, J. F. (2015). Molecular genetics of cataract. Prog. Mol. Biol. Transl. Sci. 134, 203-218. doi: 10.1016/bs.pmbts.2015.05.004

Shin, K. H., Chung, M. S., and Cho, T. S. (1994). Effects of Furanocoumarins from Angelica dahurica on aldose reductase and galactosemic cataract formation in rats. Arch. Pharm. Res. 17, 331-336.

Shin, K. H., Lim, S. S., and Kim, D. K. (1998). Effect of byakangelicin, an aldose reductase inhibitor, on galactosemic cataracts, the polyol contents and $\mathrm{Na}^{+}, \mathrm{K}^{+}$ATPase activity in sciatic nerves of streptozotocin-induced diabetic rats. Phytomedicine 5, 121-127. doi: 10.1016/S0944-7113(98)8000880001

Shu, Z., Li, X., Rahman, K., Qin, L., and Zheng, C. (2016). Chemical fingerprint and quantitative analysis for the quality evaluation of Vitex negundo seeds by reversed-phase high-performance liquid chromatography coupled with hierarchical clustering analysis. J. Sep. Sci. 39, 279-286. doi: 10.1002/jssc. 201500796

Shukla, R., Srivastava, S., Dwivedi, P. K., Sarkar, S., Gupta, S., and Mishra, A. (2013). Preliminary pharmacognostical and phytochemical investigations on the various part of Typha angustifolia. Int. J. Biol. Phamr. Res. 4, 19-22.

Siems, K., Weigt, F., and Wollenweber, E. (1996). Drimanes from the epicuticular wax of the fern Nephrolepis biserrata. Phytochemistry 41, 1119-1121.

Silva, M., and Stück, R. (1962). On the occurrence of oleanolic acid in Boquilla trifoliolata (DC) Dcne. Arch. Pharm. Ber. Dtsch. Pharm. Ges. 295, 58-59.

Singh, B., Kumar, D., and Singh, R. (2012). Phytotherapeutics for management and prevention of cataract generation. Phytopharmacology 3, 93-110.

Snow, A., Shieh, B., Chang, K.-C., Pal, A., Lenhart, P., Ammar, D., et al. (2015). Aldose reductase expression as a risk factor for cataract. Chem. Biol. Interact. 234, 247-253. doi: 10.1016/j.cbi.2014.12.017

Snytnikova, O. A., Tsentalovich, Y. P., Stefanova, N. A., Fursova, A. Z., Kaptein, R., Sagdeev, R. Z., et al. (2012). The therapeutic effect of mitochondria-targeted antioxidant SkQ1 and Cistanche deserticola is associated with increased levels of tryptophan and kynurenine in the rat lens. Dokl. Biochem. Biophys. 447, 300-303. doi: 10.1134/S1607672912060087

Söderberg, P. G., Talebizadeh, N., Yu, Z., and Galichanin, K. (2016). Does infrared or ultraviolet light damage the lens? Eye 30, 241-246. doi: 10.1038/eye.2015.266

Song, E., Sun, H., Xu, Y., Ma, Y., Zhu, H., and Pan, C.-W. (2014). Agerelated cataract, cataract surgery and subsequent mortality: a systematic review and meta-analysis. PLoS One 9:e112054. doi: 10.1371/journal.pone. 0112054

Sreelakshmi, V., and Abraham, A. (2016). Cassia tora leaves modulates selenite cataract by enhancing antioxidant status and preventing cytoskeletal protein loss in lenses of sprague dawley rat pups. J. Ethnopharmacol. 178, 137-143. doi: 10.1016/j.jep.2015.12.012

Su, H.-G., Yang, H., Meng, C.-W., Peng, C., Guo, L., and Dai, O. (2016). Study on chemical constituents of seeds of Croton tiglium and their cytotoxicities. Zhongguo Zhong Yao Za Zhi 41, 3620-3623. doi: 10.4268/cjcmm2016 1920

Sunkireddy, P., Jha, S. N., Kanwar, J. R., and Yadav, S. C. (2013). Natural antioxidant biomolecules promises future nanomedicine based therapy for cataract. Coll. Surfaces B Biointerfaces 112, 554-562. doi: 10.1016/j.colsurfb.2013. 07.068

Taylor, H. R. (2016). The global issue of vision loss and what we can do about it: José Rizal Medal 2015. Asia Pac. J. Ophthalmol. 5, 95-96. doi: 10.1097/APO. 0000000000000188

Taysi, S., Abdulrahman, Z. K., Okumus, S., Demir, E., Demir, T., Akan, M., et al. (2015). The radioprotective effect of Nigella sativa on nitrosative stress in lens tissue in radiation-induced cataract in rat. Cutan. Ocul. Toxicol. 34, 101-106. doi: $10.3109 / 15569527.2014 .910802$
Tewar, R. C., Kotecha, M., Sharma, A. K., and Sharma, P. (2013). Ethno-medicinal heritage of chandi devi hill's of Haridwar, Uttarakhand. Int. J. Innov. Res. Dev. 2, 233-241.

Tewari, D., Mocan, A., Parvanov, E. D., Sah, A. N., Nabavi, S. M., Huminiecki, L., et al. (2017). Ethnopharmacological approaches for therapy of jaundice: Part I. Front. Pharmacol. 8:518. doi: 10.3389/fphar.2017.00518

Tewari, D., Stankiewicz, A. M., Mocan, A., Sah, A. N., Tzvetkov, N. T., Huminiecki, L., et al. (2018). Ethnopharmacological approaches for dementia therapy and significance of natural products and herbal drugs. Front. Aging Neurosci. 10:3. doi: 10.3389/fnagi.2018.00003

Tezuka, Y., Kasimu, R., Basnet, P., Namba, T., and Kadota, S. (1997). Aldose reductase inhibitory constituents of the root of Salvia miltiorhiza Bunge. Chem. Pharm. Bull. 45, 1306-1311.

Thiagarajan, R., and Manikandan, R. (2013). Antioxidants and cataract. Free Radic. Res. 47, 337-345. doi: 10.3109/10715762.2013.777155

Thiraphatthanavong, P., Wattanathorn, J., Muchimapura, S., Wipawee, T., Wannanon, P., Terdthai, T., et al. (2014). Preventive effect of Zea mays L. (purple waxy corn) on experimental diabetic cataract. Biomed. Res. Int. 2014:507435. doi: 10.1155/2014/507435

Toh, T., Morton, J., Coxon, J., and Elder, M. J. (2007). Medical treatment of cataract. Clin. Exp. Ophthalmol. 35, 664-671. doi: 10.1111/j.1442-9071.2007. 01559.x

Uhr, B. W. (2003). History of ophthalmology at baylor university medical center. Proc. Bayl. Univ. Med. Cent. 16, 435-438.

Umamaheswari, M., Asokkumar, K., Lalitha, V., Sivashanmugam, T., and Subhadradevi, V. (2011). Anticataract and antioxidant activities of Citrus aurantium L. Peel extract against naphthalene induced cataractogenesis in rats. J. Pharm. Res. 4, 680-682.

Umamaheswari, M., Asokkumar, K., Sivashanmugam, T., Subhadradevi, V., and Neethu, M. (2010). Anticataract activity of Erythrina stricta against naphthalene-induced cataractogenesis in rats. Bangladesh J. Pharmacol. 5, 77-81.

Valavala, V. K., Vangipurapu, R. K., Banam, V. R., Pulukurthi, U. M. A., Reddy, M., and Turlapati, N. R. (2011). Effect of mustard (Brassica juncea) leaf extract on streptozotocin-induced diabetic cataract in wistar rats. J. Food Biochem. 35, 109-124.

Vanhaecke, M., Van den Ende, W., Lescrinier, E., and Dyubankova, N. (2008). Isolation and characterization of a pentasaccharide from Stellaria media. J. Nat. Prod. 71, 1833-1836. doi: 10.1021/np800274k

Varghese, A., Gavani, U., Abraham, S., Bgt, P., and Asha, J. (2009). Phytochemical screening and antimicrobial investigation of Typha angustifolia Linn. Int. J. Chem. Sci. 7, 1905-1910.

Varma, S. D., Chand, D., Sharma, Y. R., Kuck, J. F. J., and Richards, R. D. (1984). Oxidative stress on lens and cataract formation: role of light and oxygen. Curr. Eye Res. 3, 35-57.

Vashistha, B. D., and Kaur, M. (2013). Floristic and ethno botanical survey of Ambala District, Haryana. Int. J. Pharm. Biol. Sci. 4, 353-360.

Vats, V., Yadav, S. P., Biswas, N. R., and Grover, J. K. (2004). Anti-cataract activity of Pterocarpus marsupium bark and Trigonella foenum-graecum seeds extract in alloxan diabetic rats. J. Ethnopharmacol. 93, 289-294. doi: 10.1016/j.jep.2004.03. 032

Vibin, M., Siva Priya, S. G., N Rooban, B., Sasikala, V., Sahasranamam, V., and Abraham, A. (2010). Broccoli regulates protein alterations and cataractogenesis in selenite models. Curr. Eye Res. 35, 99-107. doi: 10.3109/02713680903428991

Wang, T., Zhang, P., Zhao, C., Zhang, Y., Liu, H., Hu, L., et al. (2011). Prevention effect in selenite-induced cataract in vivo and antioxidative effects in vitro of Crataegus pinnatifida leaves. Biol. Trace Elem. Res. 142, 106-116. doi: 10.1007/ s12011-010-8752-8758

Wang, X., Sun, J., Dang, G. F., Gao, Y., Duan, L., and Wu, X. Y. (2015). Antioxidant content and cytological examination of aqueous fluid from patients with agerelated cataracts at different stages. Genet. Mol. Res. 14, 6251-6255. doi: 10. 4238/2015.June.9.11

Watanabe, T., Rajbhandari, K. R., Malla, K. J., Devkota, H. P., and Yahara, S. (2013). A Handbook of Medicinal Plants of Nepal Supplement I. Kanagawa: Ayurseed Life Environmental Institute, 50-51.

Wu, J., Li, X., Wan, W., Yang, Q., Ma, W., Chen, D., et al. (2017). Gigantol from Dendrobium chrysotoxum Lindl. Binds and inhibits aldose reductase gene to 
exert its anti-cataract activity: an in vitro mechanistic study. J. Ethnopharmacol. 198, 255-261. doi: 10.1016/j.jep.2017.01.026

Wu, T.-H., Liao, J.-H., Hou, W.-C., Huang, F.-Y., Maher, T. J., and Hu, C.C. (2006). Astaxanthin protects against oxidative stress and calcium-induced porcine lens protein degradation. J. Agric. Food Chem. 54, 2418-2423.

Yamakoshi, J., Saito, M., Kataoka, S., and Tokutake, S. (2002). Procyanidin-rich extract from grape seeds prevents cataract formation in hereditary cataractous (ICR/f) rats. J. Agric. Food Chem. 50, 4983-4988. doi: 10.1021/jf0201632

Youn, H.-Y., McCanna, D. J., Sivak, J. G., and Jones, L. W. (2011). In vitro ultraviolet-induced damage in human corneal, lens, and retinal pigment epithelial cells. Mol. Vis. 17, 237-246.

Yusuf, M., Wahab, M. A., Chowdhury, J. U., and Begum, J. (2006). Ethno-medicobotanical knowledge from Kaukhali proper and Betbunia of Rangamati District. Bangladesh J. Plant Taxon. 13, 55-61.

Zhang, J., Mao, X., and Zhou, Y. (1995). Silybin decreases erythrocytic sorbitol level and improves peripheral nerve conduction velocity in patients with non-insulin dependent diabetes mellitus. Chin. J. Integr. Tradit. West. Med. 1, 84-86.

Zhang, X., and Hu, Y. (2012). Inhibitory effects of grape seed proanthocyanidin extract on selenite-induced cataract formation and possible mechanism.
J. Huazhong Univ. Sci. Technol. Med. Sci. 32, 613-619. doi: 10.1007/s11596-0121006-6

Zhu, M., Dong, X., and Guo, M. (2015). Phenolic profiling of Duchesnea indica combining macroporous resin chromatography (MRC) with HPLC-ESIMS/MS and ESI-IT-MS. Molecules 20, 22463-22475. doi: 10.3390/molecules 201219859

Conflict of Interest Statement: The authors declare that the research was conducted in the absence of any commercial or financial relationships that could be construed as a potential conflict of interest.

Copyright (c) 2019 Tewari, Samoilă, Gocan, Mocan, Moldovan, Devkota, Atanasov, Zengin, Echeverría, Vodnar, Szabo and Crişan. This is an open-access article distributed under the terms of the Creative Commons Attribution License (CC BY). The use, distribution or reproduction in other forums is permitted, provided the original author(s) and the copyright owner(s) are credited and that the original publication in this journal is cited, in accordance with accepted academic practice. No use, distribution or reproduction is permitted which does not comply with these terms. 